\title{
Following Traces Of A Public Open Space From 14th Century: Bursa Orhan Gazi Square In Turkey
}

\author{
İmran Satış ${ }^{1}$, Selen Durak ${ }^{2}$, Tülin Vural Arslan ${ }^{3}$
}

\begin{abstract}
In this study, the location, the significance and the physical and social changes of Orhan Gazi Square, which is one of the important public open spaces in Bursa, Turkey have been analyzed. It is aimed to reveal the phases that the square has experienced until it has reached today's practice of use. It is significant to uncover the historic traces of Orhan Gazi Square from past to present in order to understand its value and characteristics. By this research and evaluation, it is aimed to contribute to the projects in regard to the square to be developed in the future considering its physical and social sustainability. In order to support the claims given in the study, several maps showing the development of construction activities and the square during different periods have been reorganized through the use of existing maps. In addition, old photographs from several archives and photographs showing the actual condition of the square have been used. Although the idea of rearranging the Orhan Gazi Square has remained on the agenda, it is considered that there is no need to make any radical interventions in the square. The city dwellers' changing needs can be met with small-scale arrangements and changes to be made on site.
\end{abstract}

Key Words: Public Open Space, Orban Gazi Square, Ottoman Period, Republican Period, Bursa

\section{Introduction}

The square is one of the most important elements of the urban pattern. The square, a public open space where all the city dwellers come together, was taken in hand with a different spatial understanding in every culture. Reading changes taking place in squares -carrying traces of different periods of cities in the historical process- is effective in understanding the physical, social and economic transformations of a city. The purpose of this study is to investigate the transformation of the Orhan Gazi Square, which has been the focal point of Bursa and an important attraction center due to the characteristics of the buildings around it since the foundation of the city. As an evaluation method, the maps of different periods were examined comparatively based on the obtained data in company with the literature analysis. There are three main periods significant for the development of Orhan Gazi Square as a public open space determined as Pre-Ottoman period, Ottoman period and Republican period. Since the data and the resources belonging to pre-Ottoman period are limited, an evaluation over maps couldn't be available.

The changes of Orhan Gazi Square in the Ottoman period were examined in three separate periods by taking important thresholds into consideration. The first threshold is the early period between the 14th and the 16th centuries which began with the construction of the first sultan complex (Orhan Complex) and continued with the 
discussed as the second threshold. Moreover, in the 19th century, the western construction of the commercial buildings around it. The spatial effects of the economic recession and the political crises observed in the 17th and the 18th centuries were urbanization approaches observed in the Ottoman period depending on the Westernization Movements were evaluated as the third threshold. The stages of these changes were displayed comparatively on the maps.

Moreover, the important thresholds in the Republican Period were taken in hand in four periods. Initially, the effects of the decisions made by the Western planners in relation to the city on the square were examined. Secondly, the reconstruction works made in the area -greatly damaged during the 1958 Grand Bazaar Fire- were mentioned. Thirdly, the processes of the first urban design project developed for the square in 1983 were mentioned. Finally, new projects developed starting from 2011 on for the area and the present use of the area were discussed.

Reading the traces of the important historical periods of Orhan Gazi Square, that maintained its existence since Bursa became the first capital of the Ottoman Empire, is very important in terms of understanding the specific characteristics of the square. This evaluation aims to make a contribution to the achievement of physical and social sustainability of the projects and approaches to be developed for the area in the future.

\section{Historical Development Of Bursa}

Bursa was home to many civilizations throughout the history. The first settlements date back to 6000 B.C. Prior to the Ottoman conquest, the name of the city was Prusia. Located on the outskirts of the Mount Olympus, the city was probably founded by Prusias I in 187 B.C. However, according to Plinius, the governor of Bithynia in the Roman period, the city was founded by Hannibal (Bengisun, 2010). Prusa was a city of the Bithynia Kingdom until 74 B.C. and after this date, it was connected to Rome (Şahin 2006). In the Roman period, Prusa was a middle class city of the state of Bithynia (Bengisun, 2010). After 395, with the splitting of the Roman Empire into two parts, the Byzantine domination started in the city. The city was conquered by Ottomans in 1326 .

When Bursa was conquered by the Sultan Orhan, there were about 1000 houses, 7 churches or monasteries, a bazaar composed of about 20 shops and a bath house in seven neighborhoods inside the citadel of Bursa. Moreover, outside the citadel, there were small settlements inhabited by Jews, Rums in limited number and other foreigners and there was a market place where silk was traded (Şahin, 2006).

After the conquest, a part of the church inside the citadel was converted into mosque and the Tekfur Palace continued to be used as the Bey Palace accomodated by the governers of Byzantine and Ottoman periods successively (Yenal, 1996). Together with the Sultan Orhan's getting a complex built on the east of the citadel in the 1340s, the center of this new Ottoman city started to develop (Dostoglu, 1999). New housing areas developed over time around this complex built outside the citadel. In the advancing years, together with the other complexes built on the west and east of the city, the development of the city of Bursa was determined. 
In the following years, Murat I got a complex built on the west side of the city in the neighborhood of Cekirge in the 1370s; then Bayezid I got another complex built on the east side of the city in the district of Y1ldirım in the 1390s; after that, Celebi Mehmet got another complex on the east side of the city in the neighborhood of Yesil in the 1420s; finally, Murat II got the Muradiye complex built just outside the citadel in the 1440s. In the course of time, new housing areas were established around the complexes. Moreover, the other small mosques built outside the complexes made important contributions to the formation of neighborhoods as well (Bursa and Cumalik1zik Management Plan, 2013).

\section{Historical Development Of Orhan Gazi Square}

\subsection{Use of the Area in the Pre-Ottoman Period}

Unfortunately, there is not much information about the situation of the area in the pre-Ottoman period. However, it is known that the area, called Orhan Gazi Square today, and the buildings belonging to the Orhan Complex were built at a place called At Pazar1 (Horse Market) in the Ottoman period. The Ottoman historian, Nesri, reported that Balık Pazar1 (Fish Market) was located just outside the citadel on the bank of a branch of Gokdere river flowing in the 14th century and At Pazar1 (Horse Market) was located on the other bank. It is predicted that these markets were also used as the places where the local trade took place in the Byzantine period (Yenal, 2011). Moreover, during the excavations following the big Grand Bazaar fire in 1958, Bithynian graves were found (Vural Arslan, 2010). Even between the years of 1983 and 1985, the proposal of building a two-storey car park underground -within the scope of the square project designed by the Arolats- was not accepted on the grounds that there might have existed some archeological remains belonging to old periods in the area and they might have been damaged (Dostoğlu, 1999).

\subsection{Use and Development of the Area in the Ottoman Period}

\section{4th-16th Centuries: First Reconstruction Activities and Development of the Area}

Orhan Gazi Square evolved in the course of time among the buildings constructed in the Ottoman period. Firstly, in the 1340s, Orhan Gazi got his imaret (complex) composed of a few buildings built at a place called At Pazar1 (Horse Market) then. While the place of the complex was a quiet and empty field in those times, it became the trade center of the city after the aggregation of these structures (Yenal, 1996). About the area where the complex was built, the historian, Nesri, says these: '... The place where he got the imaret built in Bursa was a quiet place - where one feared to go after the midafternoon. For, Gökdere flowed through Ballk Pazar (Fish Market) on those days. For this reason, people feared to cross the creek. Later, on the side of the creek toward the stream, At Pazar (Horse Market) was established and the place near the citadel became a bit safe. Now, there is Sultan-Han (Large Commercial Building) in the place of that At Pazar (Horse Market)' (Unat and Köymen, 1987). From what Nesri said, it is considered that the bed of Gökdere was changed and the area needed for construction was obtained in this way (Yavaş, 2011). Another 
opinion is that the water taken from Gökdere was flown down from Balık Pazar1 (Fish Market) and there was a creek there (Çetin, 2010). Even in the 1445-dated Bedrettin Pars waqf charter (vakfiye), a grain mill located next to the Şehreküstü Zawiyah is mentioned among the endowed places (Öcalan et al., 2013). However, although Evliya Çelebi says for Bursa, 'wherever you dig, water gushes out', it is known that some of the grain mills in Bursa were rotated by horses instead of water. There is also some information available about the existence of grain mills rotated by horse in Balık Pazarl (Fish Market) belonging to the Orhan Waqf and near Kapan Han (Large Commercial Building) belonging to Hasan Kethüda (Pay, 2012). Although Sultan Han, as Neşri mentions, built in At Pazar1 (Horse Market) is considered to be Ipek (Silk) Han, the han must be Emir Han (Oğuzoğlu, 2010). However, it can be stated that the place of At Pazar1 (Horse Market) was changed after this construction activity. After the construction of the han, the area, where Ipek (Silk) Han exists today, began to be known as At Pazann (Horse Market) (Yenal, 2011).

In this area to the east of the citadel was constructed the Orhan Complex composed of a mosque, an imaret (public soup kitchen), a han, a public bathhouse and a school. This urbanization model which next Ottoman sultans adopted was, hence, applied for the first time by Sultan Orhan in 1339 (Dostoğlu, 1999). It is known that the structures were surrounded by walls probably for safeguard (Figure 1). This settlement called Aşağıhisar (lower citadel) had two known gates. Taşkapı (Stone Gate) on the south and Demirkap1 (Iron Gate) on the north. Together with the development of the settlement in the course of time, it is considered that the wall was removed and the stones were used in the construction of the Grand Mosque (Pay, 2012).

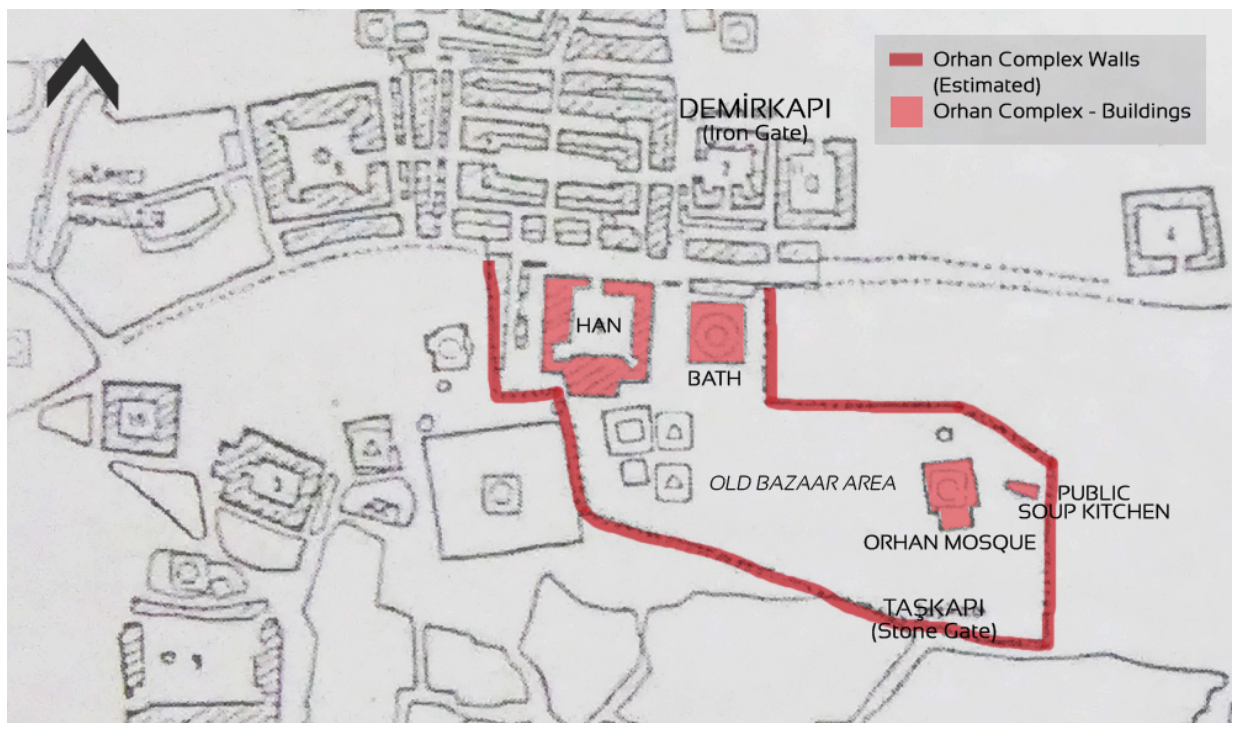

Figure 1. Structures in the area and its surroundings during the foundation period, the Orhan Complex (14th century) walls, structures, Demirkapı (Iron Gate) and Tasskapi (Stone Gate) (adapted from Yenen, 1987:88) 
The structures belonging to the Orhan Complex, which have been able to reach today, are the Orhan Mosque (a mosque with a zawiyah), Emir Han and the Orhan Public Bathhouse. The bathhouse is the first downtown bathhouse of the city and its construction date must be about 1339, which is also the date of the mosque. The Orhan Bathhouse is a rather big, double bathhouse (Şehitoğlu, 2010) which is known as Aynalı Çarşı (Bazaar of Mirrors) today. Emir Han forms the western border of the complex. The han known to have been built a few years after 1336 was given the names of Bezzaz-1 Atik (Drapers' Hall) and old Bezzazistan (Drapers' Place) until 1416 (Köprülü Bağbanc1, 2007). The Orhan Mosque built in 1339 was damaged during the Bursa siege of Karamanoğlu Mehmet Bey in 1413 and was repaired upon the order of Çelebi Sultan Mehmet in 1417. Although it is known that there was a school around the mosque, the existence of a madrasah is uncertain. From the resources, it is understood that the school was a domed building located on the north of the Orhan Mosque (H1zl1, 2011; Pay, 2012). The imaret (public soup kitchen), which was the most important social facility of the period, is known to have been on the east of the Orhan Mosque, in the place of the old Municipality building (Pay, 2012). Moreover, Yenal (2011) states that the possibility that the area between the zawiyah (the Orhan Mosque) and the bathhouse (where the Koza Han (Silk Market) was built in the 15th century) was a market with agricultural quality in that period should not also be ignored.

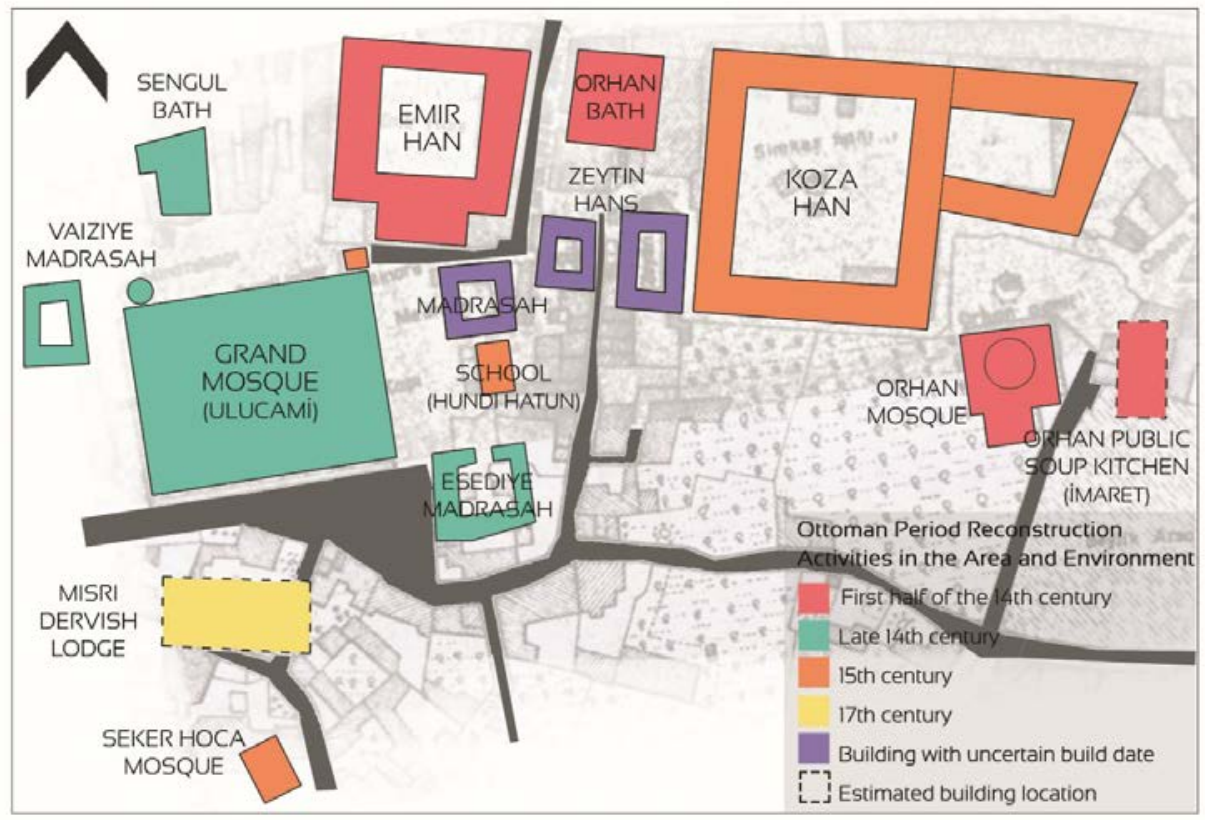

Figure 2. Structures in the area and its surroundings during the Ottoman Period between 14th and 17th centuries (adapted from 1861 Suphi Bey Map)

The construction activities starting in the first half of the 14th century also continued following the Orhan period and the structures making up today's trade center were constructed in the area (Figure 2). The mentioned area took shape together with these 
structures constructed around it. One of the structures, which has not been able to reach today, the Esediye Madrasah was built by the initiative of Hac1 Bekir Bin Arslan, one of the Ottoman notables, in the 1370s on the west of the area (on the east of the Grand Mosque). Since it was situated next to the coffin rests, it was later called Musalla (Coffin Rest) Madrasah as well (Pay, 2012).

The Grand Mosque built by the order of Sultan Yildirım Bayazid in 1399 formed the western border of the area. Although the architect of the Grand Mosque is not known for certain, it is considered that it was built by the order of Ali Neccâr or Hacı Ivaz Pasha. Although there is information in the Bursa provincial annuals like this "from its general state, it is understood that the architect of the structure was a Rum", its accuracy is questionable. The mosque underwent its most comprehensive repair after the 1855 earthquake (Yavaş, 2012). The northern border of today's square is formed by the Koza Han built by the order of Sultan Bayazid II in 1491 with the aim of providing income for his complex in Istanbul. The han located between the Orhan Mosque and the Orhan Bathhouse became the center of silk trade of Bursa. The han was built as a two-storey structure inside a rectangular courtyard with a fountain and a masjid. There is also a courtyard section called Diş Koza Han (outer silk bazaar) including stables and depots on the east of the han. Today, the access from the Orhan Gazi Square to the upper level of the Koza Han is made via the southern gate of the han.

Another structure, which has not been able to reach today, is the school built on the east of the Grand Mosque. In a waqf charter regulated in 1502 for the school understood to have been established by Hundi Hatun, a condition was laid down in relation to the teaching of reciting the Quran, praying procedures and religious services to orphan and poor children (Pay 2012). Moreover, Baykal (1982) points to the existence of probably the same school by saying 'There was the Homdi Hatun madrasah in front of the east door of the Grand Mosque. This woman was the granddaughter of Çelebi Sultan Mehmed; the construction date of the madrasah is 1486. The epigraph (No: 77) is in the museum'.

The existence of another structure, which is indirectly related to worshipping, around the Grand Mosque is mentioned in resources as well (Pay, 2012). This is muvakkithane. They were small structures where there were instruments such as clocks, etc. used to determine the time (for ezan) and astronomical observations were made. This structure around the Grand Mosque is located just on the north of the mosque next to the usedbook bazaar, but there is no information about by whom and when it was built. Again, in associated with the mosque, it is understood from a document dated 1634 that restrooms were built on the east side of the Grand Mosque. Moreover, on the south of the Grand Mosque, at the place where the post office is located today, there was the Misri Dergahi (dervish lodge) in that period. The mentioned structure was built by the initiative of Niyazi-i Misri in 1670. The dervish lodge is composed of a halvethane (place of reclusion), dervish rooms and a school (Dörtok Abac1, 2001). The dervish lodge is in front of the Şeker Hoca Mosque. Misri Niyazi got this lodge built with the help of folks because of the crowd of people coming to the Şeker Hoca teaching house for lesson and sermon (Baykal, 1982).

Again, two of the structures, which have not been able to reach today, are the small and the grand Zeytin (Olive) Hans. Ayverdi states that these hans were built between 
Koza Han and Emir Han and one of them was called Small Zeytin Han and the other one was called Grand Zeytin Han. In a newspaper dated 1918, it was reported that the Small Zeytin Han would be sold. It was reported to have 43 rooms, 3 stables, 1 coffeehouse and 7 shops and received running water from Gökdere. It is understood that this and the like hans reported to have existed in the early 20th century were generally wooden structures and collapsed and disappeared easily (Yalman, 2011).

Another type of places around the Grand Mosque is coffeehouses. The biggest of these is Emir Kahve, which is a decorated and embroidered coffeehouse. Again, the Kemeralt1 and Hasediye coffeehouses located in the courtyard of or near the Grand Mosque are the other coffeehouses known by their names (Pay, 2012). Many houseanterooms understood from the waqf charters to have belonged to Hundi Hatun's mother, Bülbül Hatun, Mevlana Çelebi Cafer and Karaçelebizade (Pay, 2012) constitute the other structure groups located around the area.

\section{Economic Recession between the 17th-18th Centuries and the Physical Condition of the Area}

The effects of the stagnation observed in the socio-economic structure between the 17 th and 18th centuries reflected to the urban place (Cezar, 1983). With the discovery of the new trade routes, the importance of the Mediterrenean trade and the Silk Road decreased and this naturally affected the city of Bursa. Moreover, the Jalali riots starting in the middle of the 16th century affected the physical structure of the city negatively and many hans and bazaars were damaged. Even due to these riots, the guard walls called Aşağ1 Kale (Lower Fortress) were built. These walls were made with the aim of protecting the housing settlements in the developing parts of the city.

Due to these changes in social and commercial activities, there were no new construction recorded in this period in the city center and the Orhan Gazi Square. It can be stated that the city and the trade center preserved their physical states until the middle of the 19 th century.

\section{Effects of the 19th Century Westernization Movements on the Physical Structure of the Area}

In 1855, an earthquake with destructive effects on Bursa took place. After the earthquake, engineer Suphi Bey from the General Staff drew the first cadastral plan of the city in 1858 and published in 1861 (Saint-Laurent, 1996). On this map, all the structures, collapsed or standing, were shown. According to the map, it is understood probably from the existence of aforementioned madrasah, school, han and houses, there was a settlement on the west of the area described as the Orhan Gazi Square (Figure 3). 


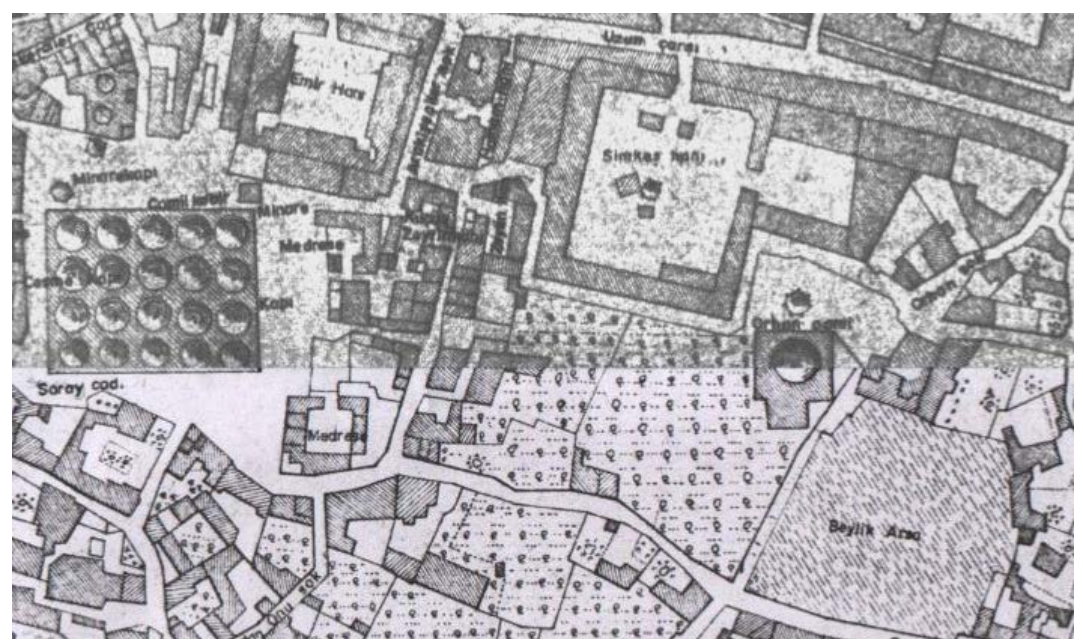

Figure 3. Spatial development in the area according to 1861 Suphi Bey map (Şabin, 2006:141)

Changes in political and social structure starting from the second half of the 19th century were observed in Bursa, too. In that period, while France became mechanized in silk fabric industry, the need for Bursa silk increased and an increase was observed in the number of filatures in Bursa. However, since the long distance trade having been made via caravans in the past also underwent changes, the hans in cities became non-functional and, hence, obsolescent. In this period, together with the Imperial Edict of Gulhane (Tanzimat Ferman1), the modernization movement started and Bursa was one of the cities having been affected by these changes. In this respect, the first practices in Bursa were carried out in the periods when Ahmet Vefik Pasha was the inspector and the governor. Ahmet Vefik Pasha performed two important works affecting the development of the area. The first practice was the widening of Sarayönü Street, known as Atatürk Street today, in 1863 during the inspectorhip years of Ahmet Vefik Pasha (Kaplanoğlu, 2012) and changing its name to Hükümet Street and the other practice was the construction of the Municipality building by architect Kütahyalı Şehbender on the east of the Orhan Mosque in 1879. It is known that this building was built on the area where there had been an imaret and a madrasah built in the period of Sultan Orhan (Dostoğlu, 1999). Hasan Taib Efendi mentions the Municipality building in his book published in 1905: 'There is the Municipality building opposite the mosque and on the left, perfectly built on the street. Between the Municipality building and the minaret is a street. There is the Millet (Nation) garden with its spacious view at the same place. It has a large coffee house on the east part of the garden and its revenue belongs to the Municipality. For the enthronement and birthday celebrations of the Sultan, this area has been allocated. At these nights, festivals are organized in the garden. Both the garden and its circle have reached such an appearance thanks to the works of Mahmud Celaleddin Pasha, one of the old governors. The garden is extremely beautiful; the fountain pool in the center is surrounded by an iron fence and it has a unique beauty. The gate of the garden is opened to Sarayönü Street. Down the Municipality building is the imaret of Orhan Gazi's royal highness. From this imaret, hot meal, pilaf (cooked rice) and saffron and rice dessert are cooked and served to students and poor 
people' (Birgül, 2009). On the map of 1880 (Figure 4), the Millet (Nation) garden was described as Jardin Municipal.

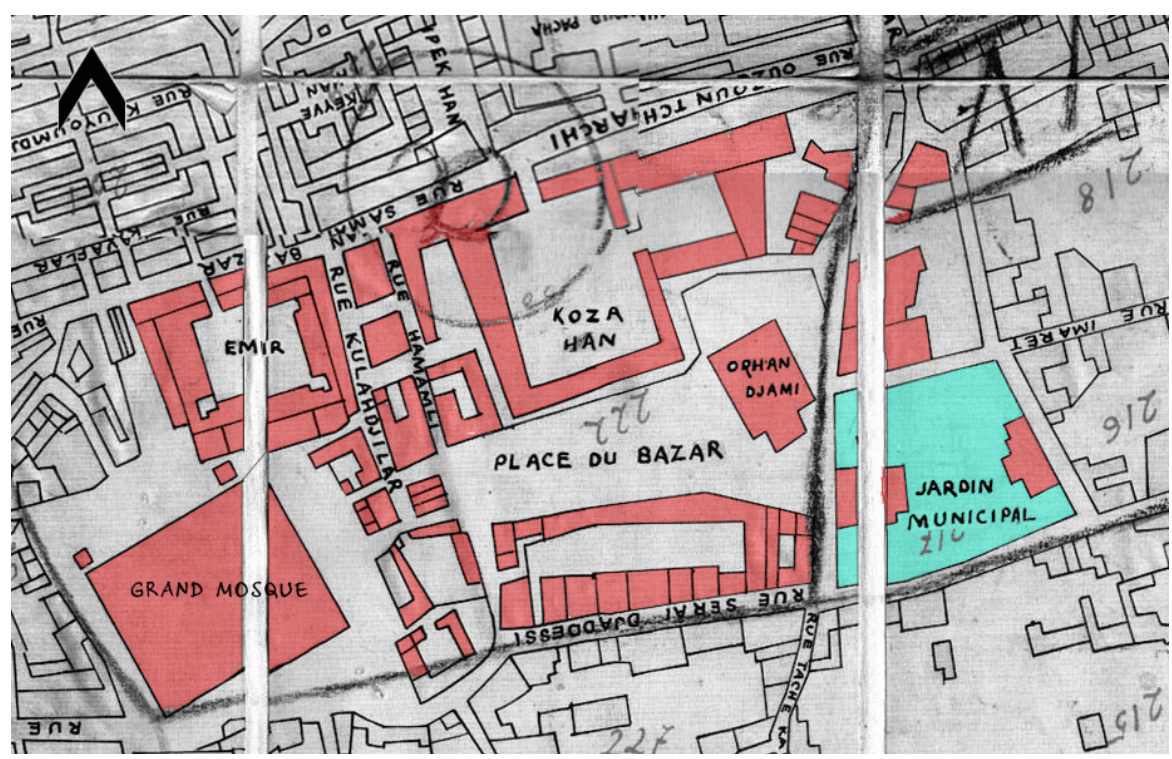

Figure 4. 1880 French Insurance map showing the structures in the area and its surroundings including the Municipal Garden (Dostoğlu et.al., 2010:544)

In the period of Ahmet Münir Pasha (1891-97), unfinished roads around the Grand Mosque were completed. In the period of Governor Mümtaz Reşit Pasha (1903-06), the transportation axes, which are also the most important and intensively used routes today, were opened (Köprülü Bağbanc1, 2007). Moreover, Atatürk Street was completed in this period as well. With these urbanization practices performed in the late 19th century and the early 20th century, the southern border of the Orhan Gazi Square was determined.

When the French Insurance map of 1880 is examined, it is seen that there were probably structures with commercial function in the part of the area which was close to Sarayönü Street. Thus, construction activities started in the area, nearly a great part of which was empty, in the previous centuries. In this period, one of the structures existing in the area and in its surrounding was the fountain built by the order of Governor Münir Pasha on the east of the Grand Mosque in 1895 (Çobanoğlu, 2010). The fountain is also in use today. Another structure was the building constructed by the order of the Union and Progress (Ittihat ve Terakki) Club in the early 1910s and having remained in use until 1918 and then settled by the Ottoman Bank starting from the proclamation of the Republic until 1971 (Dostoğlu, 1999) (Figure 5). Kirayoğlu (2012) claimed that the building reflected all the features of a period together with its architecture. It was one of the constructions that had to be preserved with its entrance door, its windows and its inscription including the three principles of the Committe of Union and Progress (Ittihat ve Terakki) written in the old text. 


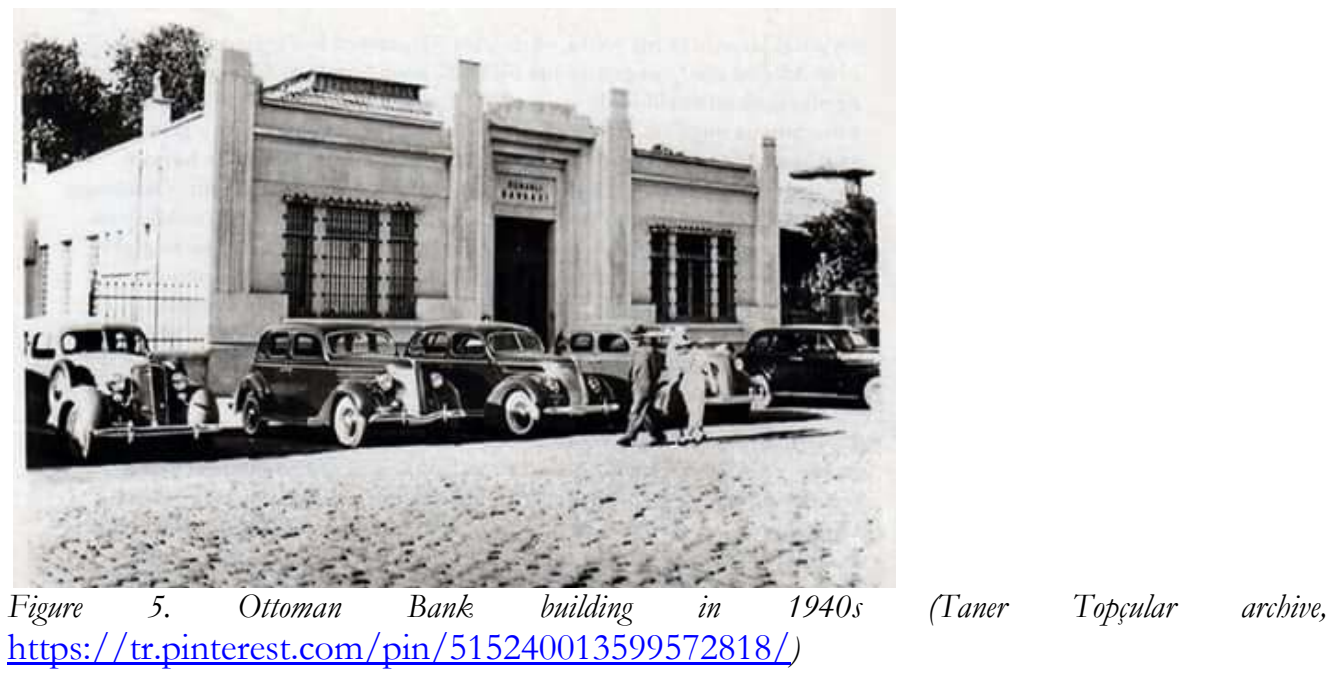

\subsection{Use and Development of the Area in the 20th and the Early 21st Century during Republican Period}

\section{Effects of the Decisions of Western Planners}

The practices performed in the area at the beginning of the 20th century continued in the Republican period as well and new structures were built in order to meet the newly-arising needs. Besides, in this period, planning works were done. According to the 1924 Lörcher Plan, the Citadel entry of Atatürk Street was arranged and according to the 1941 Prost Plan, the Grand Mosque - Atatürk Street (Gazi Street) was opened (Köprülü Bağbanc1, 2007).

When the construction activities performed around the area (the Orhan Gazi Square) are examined, it is seen that the Tayyare Cinema building was built on the east of the Municipality garden in 1932 in accordance with Arif Hikmet Koyunoğlu's project having won the first prize in the contest organized by the Turkish Aeronautical Associaton in 1930 (Figure 6). The Municipality garden was a quite wide area located between the Municipality building and the street. 


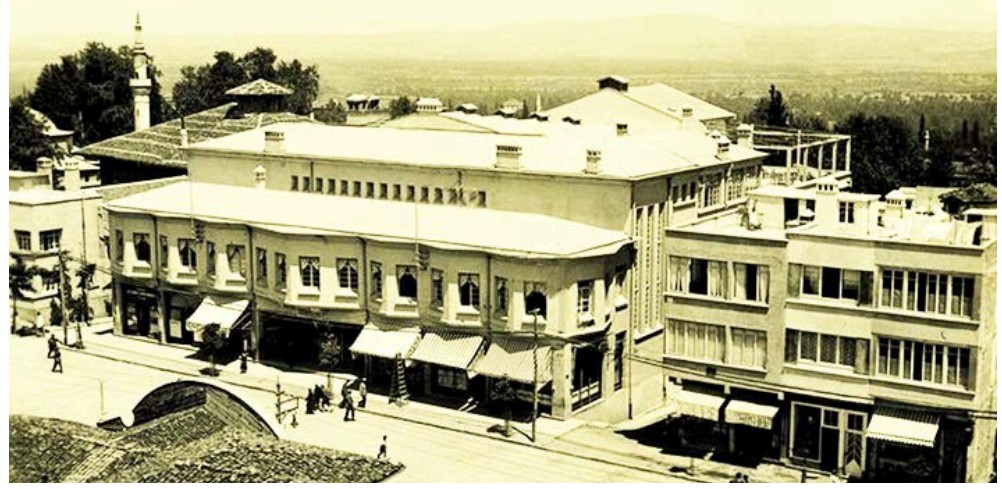

Figure 6. Tayyare Cinema and Atatürk Street in 1950s (Mustafa Kulac archive, https:/ / wmw.haber16.com/ fotogaleri/nerede-o-eski-bursa-1/44/resim/4)

Kaplanoğlu (2012) states that the garden was opened in 1909; it was the property of the Municipality and it was famous for its tea garden and large coffee house; formerly there was the grave of Sheikh Küşteri there and, for this reason, it was called Küşteri Square. In the advancing years, the Romans Tea Garden took its place in this area. On the corner of the garden facing the street was the Mountaineering Club's two-storey building constructed in 1933, which firstly served as a branch of Turkkusu (civil aviation school). Then, the structure was used by the Bank of Istanbul. This structure was one of the structures not having been able to reach today as well (Figures 7 and 8).

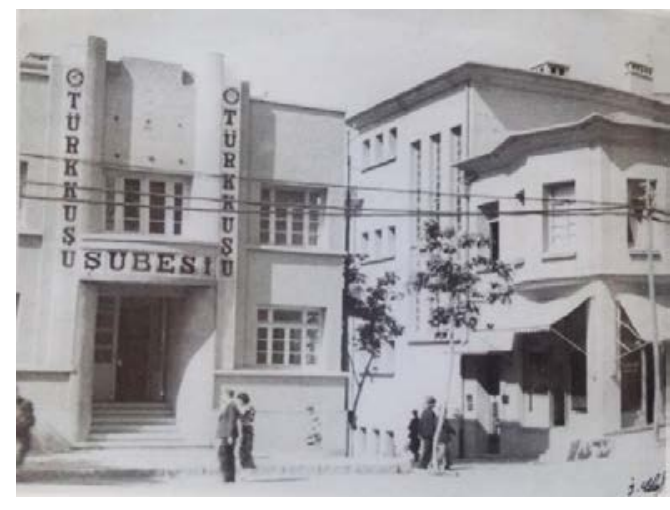

Figure 7. Civil aviation building (Türkekusu) in 1930s (Demirağ, 2012:78)



Figure 8. Mountaineering club building in 1940s (Demirăg, 2012:88)

Kaplanoğlu (2012) states that the Musalla (Esediye) Madrasah located between the Ottoman Bank and the Grand Mosque was later replaced by the Zevk Cinema and the Istanbul Cinema; the structure burned in 1947 and was reconstructed as a performance hall by the Community Center. However, it is seen that the Esediye Madrasah did not appear on the Property-Based Bazaar Area map prepared in the years of 1924-32 (Figure 9) and on the Bazaar Area Aerial Photo dated 1938 (Figure 10). 


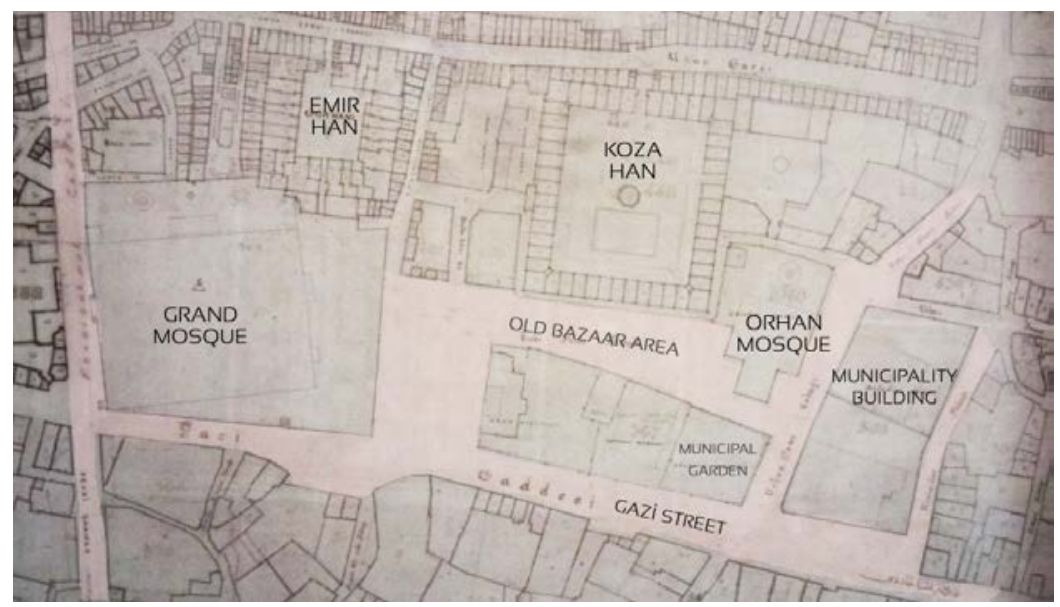

Figure 9. 1924-1932 Map of the Bazaar area based on property ownership (Dostoğlu et.al.,2010:538, 539)

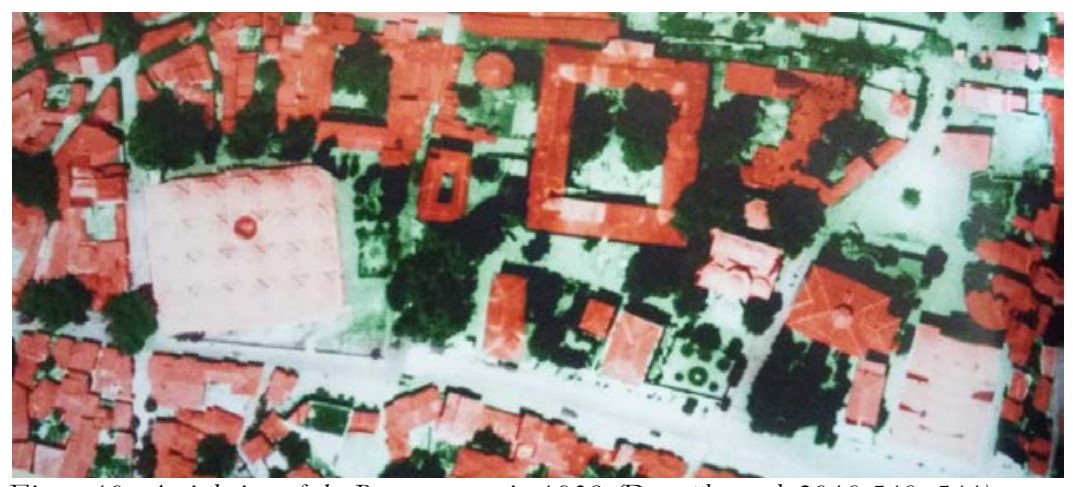

Figure 10. Aerial view of the Bazaar area in 1938 (Dostoğlu et.al.,2010:540, 541)

The structure used as a cinema building was probably another one located on the west of the Ottoman Bank (Figure 11). Besides the structures located in the area, there was a street leading from inside the bazaar to Atatürk Street and there were also bus garages around the Orhan Mosque in that period (Kaplanoğlu, 2012). Besides the garages, a petrol station, service stations and bus stops were the other structures occupying the area in that period (Figures 12 and 13). 


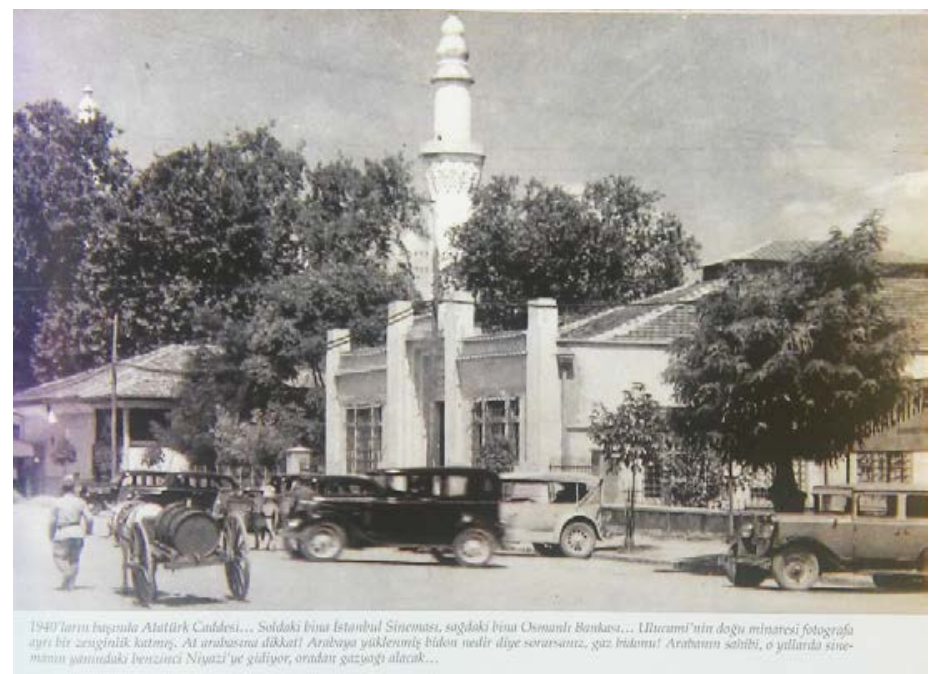

Figure 11. Ataturk Street in the beginning of 1940s with Istanbul Cinema on the left and Ottoman Bank on the right (Doruk, 2012:99)

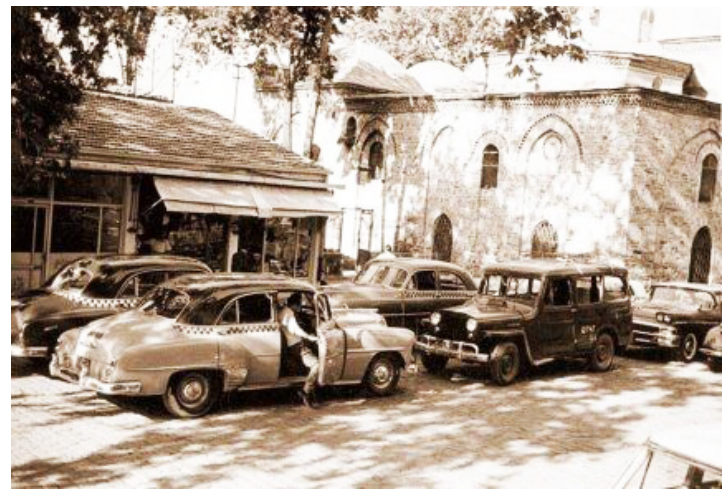

Figure 12. Cars around Orhan Mosque (Tevfik Ataberk archive,

https://tr.pinterest.com/pin/44838970663619 6006/)

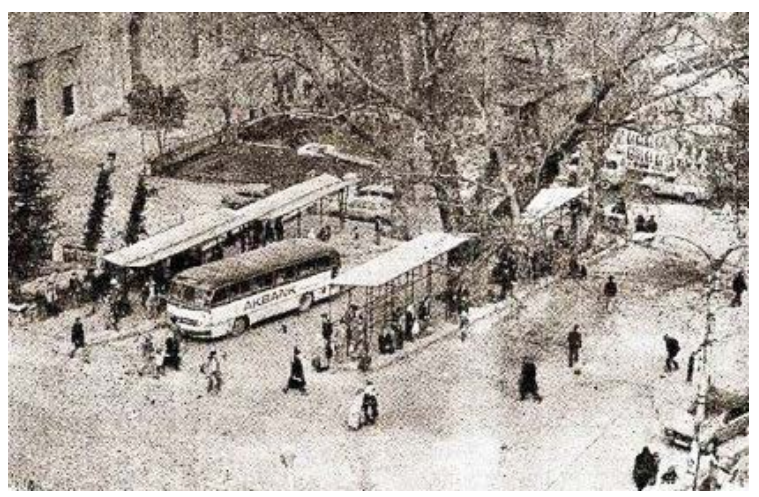

Figure 13. Bus stops in the east of Grand Mosque (Nedim Ussoy archive,

http://wowturkey.com/forum/viewtopic.php?t= 9701\&start $=780$ )

Ataturk Street framing the southern border of the Orhan Gazi Square turned into a promenade street where people went for a walk and had a rest starting from the first years of the Republic. After the construction of governmental buildings including a provincial hall, a courthouse and a finance building in 1926, a new center emerged next to the traditional city center (Figure 14). In the middle of the area surrounded by governmental buildings a square was arranged with the Statue of Ataturk (1931). This area began to be called as Heykel, which continued its existence as an administrative center until 1980s. Today, the central function of this region is rather symbolic and is being used as a commercial and cultural center (Durak and Vural Arslan 2011). Ataturk 
Street has been providing the connection between Orhan Gazi Square and Heykel and keeps the social life vivid.

Kaplanoğlu (2012) states that the busiest shops on Ataturk Street were the pudding shops until the 1950s. Besides, along the street extending to Heykel were many coffeehouses (Kemankaş, 2012). Iş Bank, which is opposite the square, on the south of the street today, was built in 1931. On the west of Iş Bank, the building of Emlak Bank (later Ziraat Bank) was built in 1948. Again, in this period, opposite the Grand Mosque was Luca Palas Hotel. Moreover, the aforementioned Misri Dervish Lodge located opposite the Grand Mosque was demolished in the late 1940s and the Bursa Central Post Office Directorate building was constructed on its place in the 1950s.

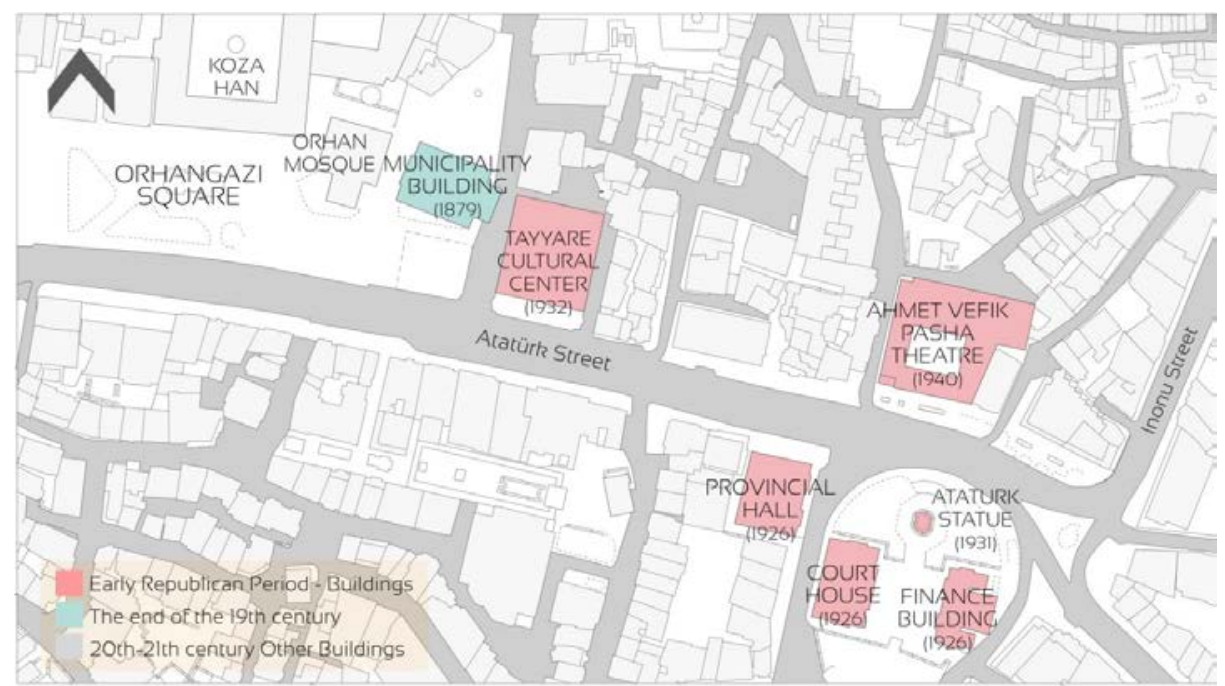

Figure 14. Heykel and Early Republican Period Buildings (Adapted from the actual map of Bursa, Bursa Metropolitan Municipality Archive, 2018)

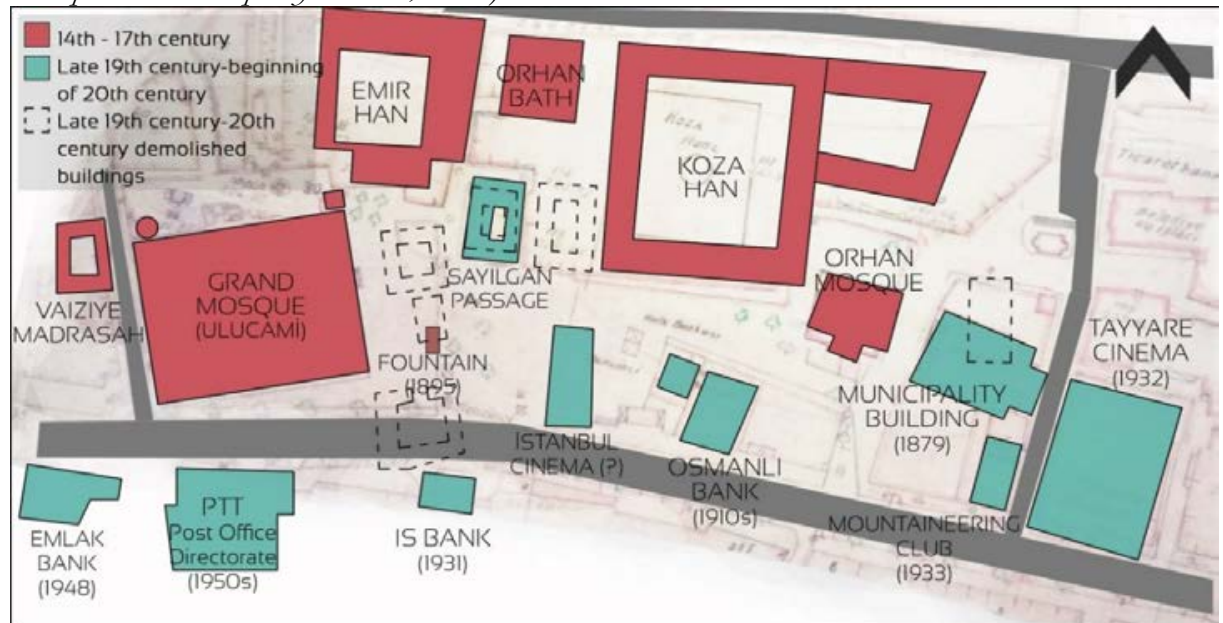

Figure 15. The structures in the area and its surroundings from the late 19th century until the half of 20th century (Adapted from Dostoğlu et. al., 2010:536, 537) 
It is observed that some of the structures in the area were demoslished and disappeared in the late 19th century and early 20th century (Figure 15). It is observed that the madrasahs (the Esediye Madrasah and the other structure specified as madrasah on maps) and the school located on the east of the Grand Mosque did not exist in that period. Again, the demolition dates of the Grand and Small Zeytin Hans located between Koza Han and Emir Han are not known; however, it is observed that the Sayllgan Passage (Altan Hotel) was constructed at the same place. In the late 19th century, the Municipality building was built in the place of the Orhan Imaret (soup kitchen). At the beginning of the 20th century, the Tayyare Cinema was built on the east of the Municipality building. Moreover, in order to meet newly-arising needs, new structures were built on the north and the south of Ataturk Street (opposite the Grand Mosque) (Figure 16).

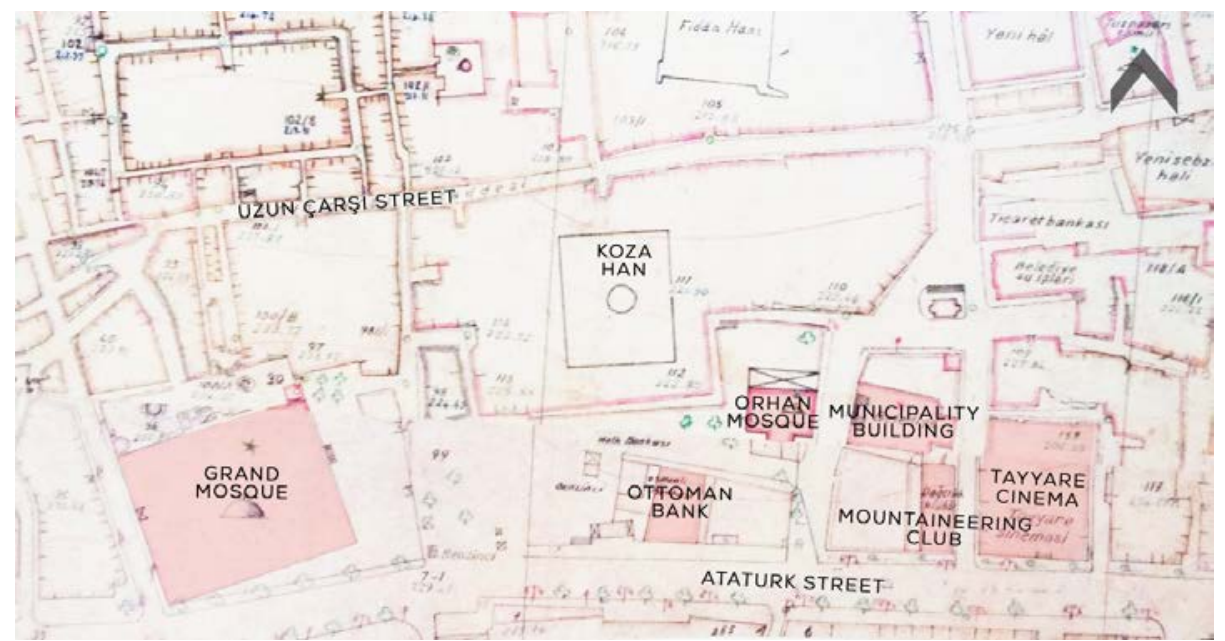

Figure 16. 1957 Bazaar area map (Dostoğlu et. al.,2010:536, 537)

\section{Post-1958 Period: Works for the Arrangement of the Area}

In August of 1958, the fire starting in a bindery in the Used-Book Bazaar spread all over the bazaar area in a short time and destroyed nearly the whole of the historical trade center (Vural Arslan, 2010). In 1960, a project team having worked under the supervision of Luigi Piccinato and under the chairmanship of Emin Canpolat prepared a master plan scaled 1/4000. According to the plan, it was suggested to restore the monumental structures located in the area and clear some shanty-type shops composed of light structures. In the plan, in a way which would affect the use of the area, an excessive amount of space was allocated for parking lots and vehicle circulation was attached importance (Figure 17). However, this plan was not applied. But still, the comprehensive conservation approach suggested by Piccinato for the area is an important acquisition for the transfer of the area to present day (Vural Arslan, 2010). 


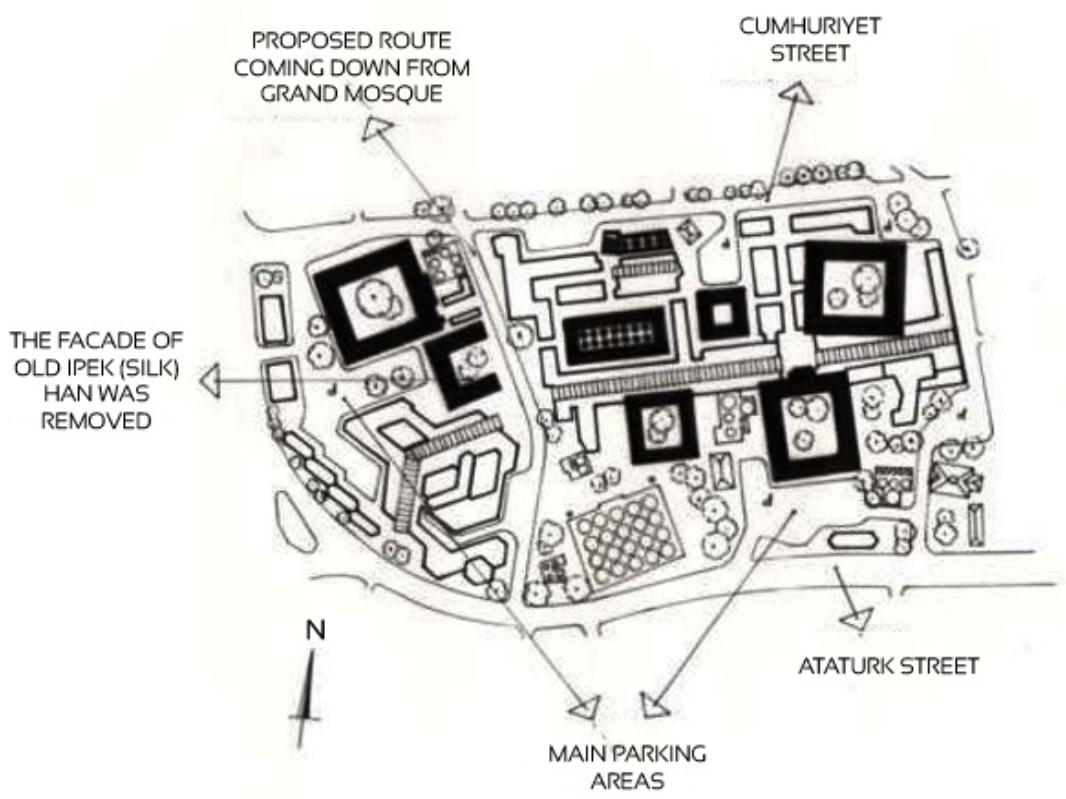

Figure 17. Land-use in the area according to Piccinato plan in 1960 (Kirayoğlu 2004:64)

After the 1960s, suggestions for the use of the area have started to appear on the agenda. The first suggestion was the construction of a car park under the area, which was made in the period of Kemal Bengü, the Mayor of Bursa, between the years of 1963 and 1973. However, this suggestion was not accepted due to the opposition of High Council of Immovable Monuments and Antiquities. Mustafa Eroglu elected mayor in 1977 wanted to remove the structures in the area and turn this place into a recreation area. However, after the military coup in 1980, the project was suspended. Moreover, the idea of arranging the area as a square appeared in 1980 (Dostoğlu, 1999).

\section{Post-1980 Period: Arrangement of the Area as a Square}

The design of the square project by Şaziment and Neşet Arolat was started in 1983. The design was aimed to highlight the historical buildings, to connect a pedestrian subway under Ataturk Street to the square, to protect the plane trees existing in the area and to enrich their surroundings with green areas, to connect the area on the north of the Municipality building with the square, and to arrange open and closed areas for cultural activities (Dostoğlu, 1999). The construction of the square was completed in 1985. The building known as the old Altan Hotel located between the Grand Mosque and Koza Han (Figure 18) was designed by the Arolats to function as a passage (Sayllgan Passage) and again a building with the same function was built on the empty piece of land next to it (Figure 19). The design of a pool was proposed. Dostoğlu (1999) states that the air ventilation chimneys of the restrooms designed underground were hidden inside a concrete structure (Figure 20) located in the middle of the pool. In addition, it is 
claimed that the level of the square was high making it impossible to see the whole front facade of Koza Han.

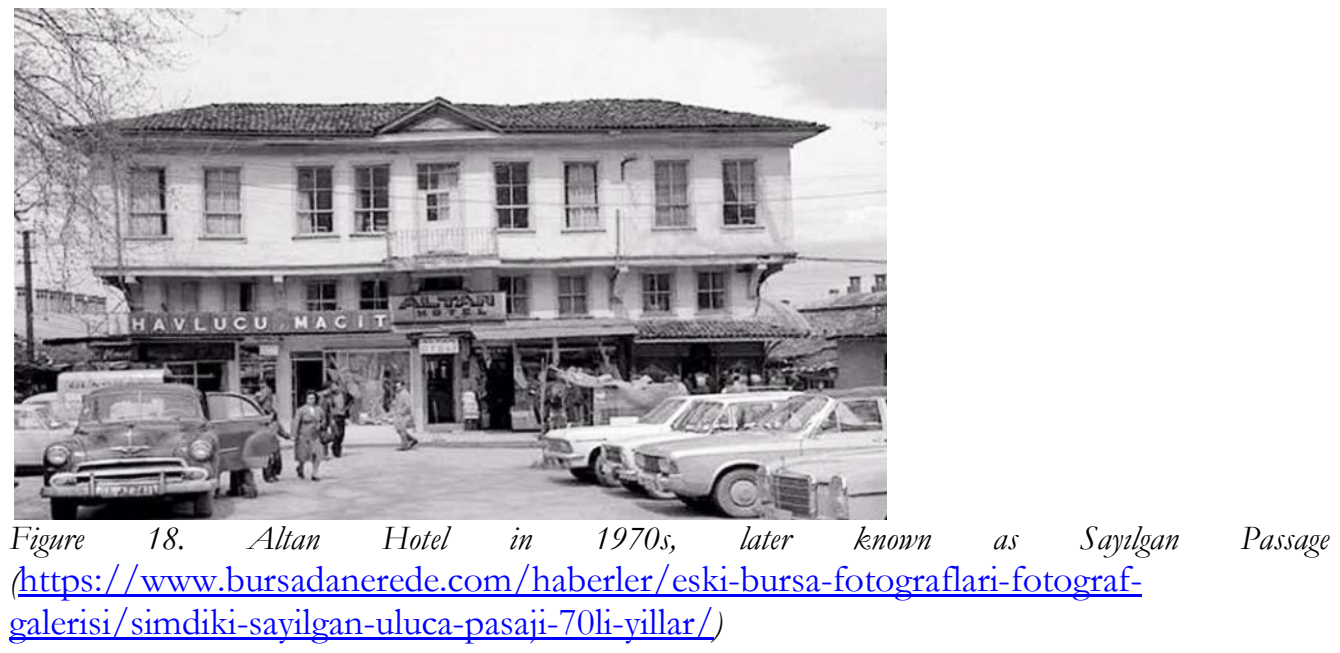

Polat (2013) expresses that the Orhan Gazi Square has been used by people since 1986 as a public open space where they can have a sit and rest, meet friends at cafes, do shopping, watch activities held on special days, perform prayers in mosques around it; shortly it has been used as a place hosting many social, cultural and commercial activities.

In 2006, Sahin examined the contribution of Orhan Gazi Square to the urban life in Bursa through a questionnaire. According to the results of this study, it was observed that the square was used both by male and female users equally; especially the user group aged above 55 preferred the square mostly and $77 \%$ of the square users lived in other quarters of the city.
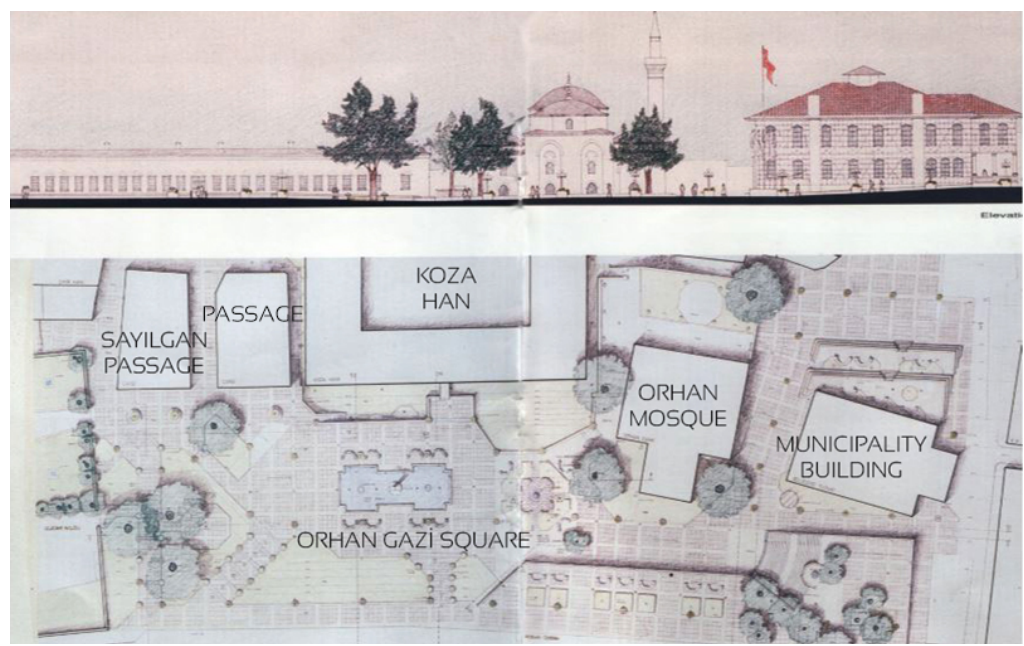

Figure 19. Orban Gazi Square and its surroundings according to Arolats design project (Sabin 2006: 152) 


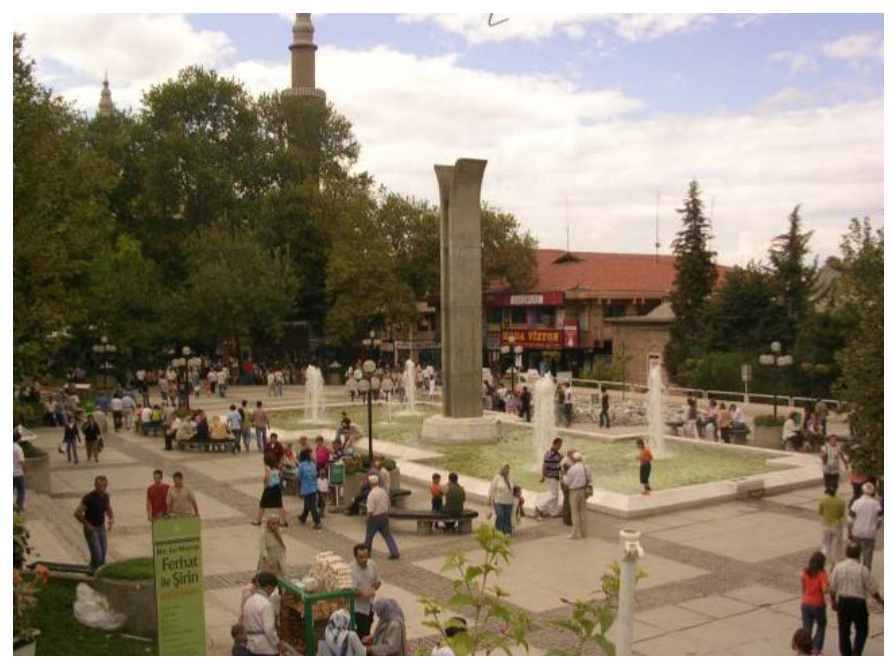

Figure 20. The pool in Orhan Gazi Square in 2005 (Sabin 2006:159)

It can be stated that the users of the square prefer the area especially for doing shopping and performing prayers in the mosques. Nearly half of the users having participated in the questionnaire found the size of the Orhan Gazi Square insufficient. The participants thought that since the square was below the road level, with the same level of the pool, it showed a closure effect and the individuals did not feel uncomfortable with the high-rise buildings located on the south of Ataturk Street. In addition, only $25 \%$ of the participants found the noise created by the traffic in Ataturk Street disturbing. Unlike contemporary buildings in the area, the features of the historical buildings located in the area such as material, color, texture affected the users positively. It was observed that public buildings located around contributed to the use of the square. The importance of the floor finishing was emphasized. It was determined that the number of seating elements were insufficient. The participants stated that the pool added visual attraction to the square; it was relaxing and refreshing; it suppressed the traffic noise; it created a place where people gathered around. Moreover, the historical buildings, the pool, the fountain and the trees located around Orhan Gazi Square created an image, specific to this place, in the memories of the users.

\section{1: The Urban Design Project Competition for the Orhan Gazi Square and its Surroundings}

In 2011, Bursa Metropolitan Municipality organized an urban design project competition for Orhan Gazi Square, which had undergone a number of changes since the time it was arranged. The purpose of the competition was to rearrange the Orhan Gazi Square and its surroundings in accordance with the identity of the historical city center in a way to meet the needs of today's users within the framework of urban, architectural and landscape design principles. In the competition, announced on 15th November 2011 and concluded on 23rd February 2012, the participants were asked to 
take into account transportation, functional distribution and physical environment when they were making principle decisions about the whole of the Historical Bazaar and the Area of Hans with the aim of associating the project area with its close surrounding.

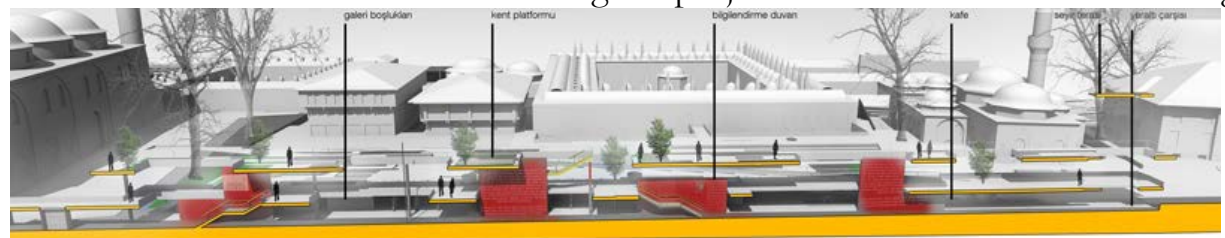

Figure 21. 1st Prize, City Platform (Arkitera, 2012a)

In the project winning the first prize, a buffer zone called 'city platform' was suggested at the level of Ataturk Street. It was considered that the square and the historical urban pattern could be viewed from this platform which was regarded as a walkway establishing the connection between the bottom and top levels and informing city-dwellers before taking them into the square (Figures 21 and 22).

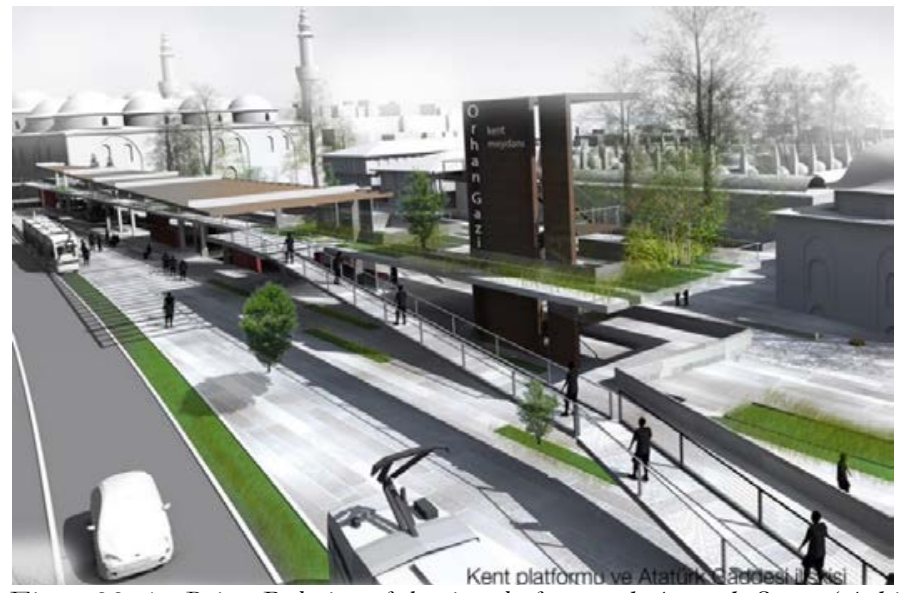

Figure 22. 1 st Prize, Relation of the city platform and Atatürk Street (Arkitera, 2012a)

Moreover, in the project winning the second prize, a transitional route was created by using the level difference between the square and Ataturk Street with the aim of regulating the pedestrian circulation and repairing the broken links in the collective memory of the city (Figure 23). 


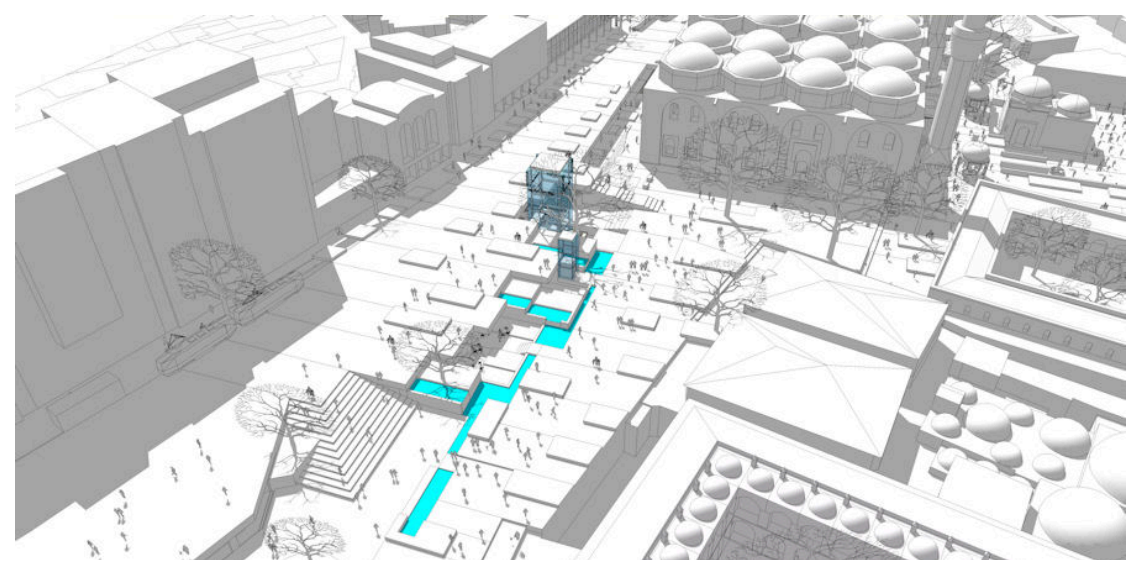

Figure 23. 2nd Prize, proposed transitional route (Arkitera, 2012b)

The project winning the 3rd prize aimed to turn the square into a city park by carrying the green pattern existing on the west of the city to the square. In the project suggesting a new spatial organization for the underpass, a strong pedestrian corridor tried to be created (Figure 24).

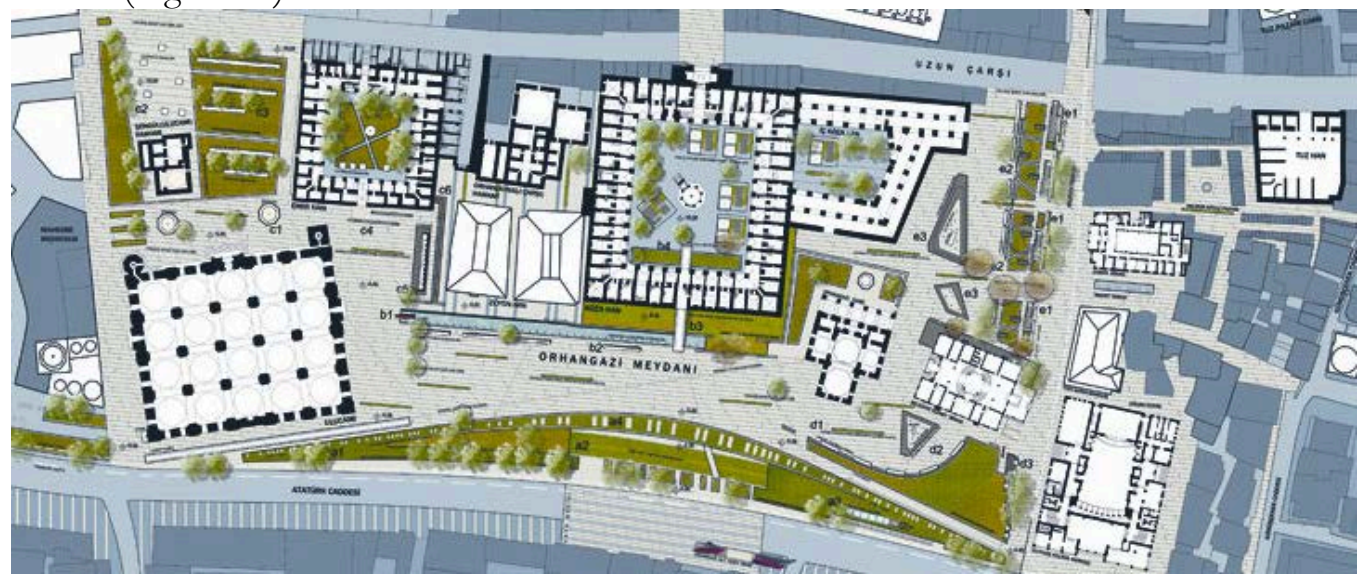

Figure 24. 3rd Prize, Orban Gazi Square plan (Arkitera, 2012c)

\section{The Present Use and Physical Condition of the Orhan Gazi Square}

The Orhan Gazi Square has managed to reach today by preserving its condition arranged in 1985. Although it was decided to implement the project winning the first prize according to the result of the competition organized in 2011, it was given up later. However, in the meantime, some changes took place in the area. These non-structural changes were mostly the implementations in relation to the practical usage of the area. The pool, which may be the most important element of the square, and the concrete statue in the middle of it were removed in 2006 and and the pool was reconstructed with some small formal interventions. Again, with the arrangement made in 2006, changes were made in the locations and forms of the seating areas. The news item published in a 
newspaper dated 02/12/2006 (Bursa Hakimiyet Newspaper, 2006) in relation to the arrangement of the square was reported like this: 'A new pool with a play of water and light is being constructed in the Orhangazi Park. It is going to be landscaped. ... With the new pool targeted to be completed in March, the Orhan Gazi Park is going to provide a different view on spring days. After the arrangement in the pool, the seating groups in the park are going to be renewed and the park located in the middle of historical places is going to get a more beautiful view.' As it is seen in the news item, on the internet environment and in the press, the square is generally called as 'the Orhan Gazi Park' both in the press and on the Internet.

In 2016, a comprehensive renewal work was carried out in the square (Figure 25), including the rearrangement of the pool, the ramp and the seating areas. The infrastructure and the floor finishing were completely renewed in the area between the Grand Mosque and the historical Municipality building. Moreover, a statue of a child feeding birds was erected on the place where there were seating units under the plane trees on the west of the square in 2017 (Figure 26).

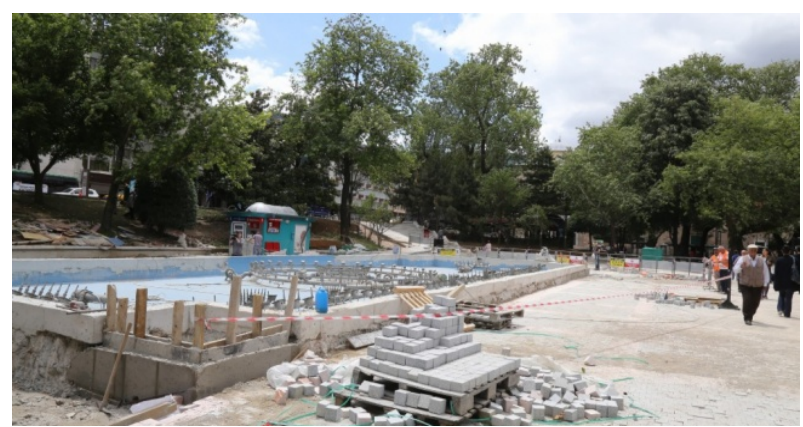

Figure 25. Reorganization of Orban Gazi Square in 2016 (Bursa Haber, 2016. http://bursadabirgun.com/orhangazi-parkinda-calismalar-ne-zaman-tamamlanacak5922.html)

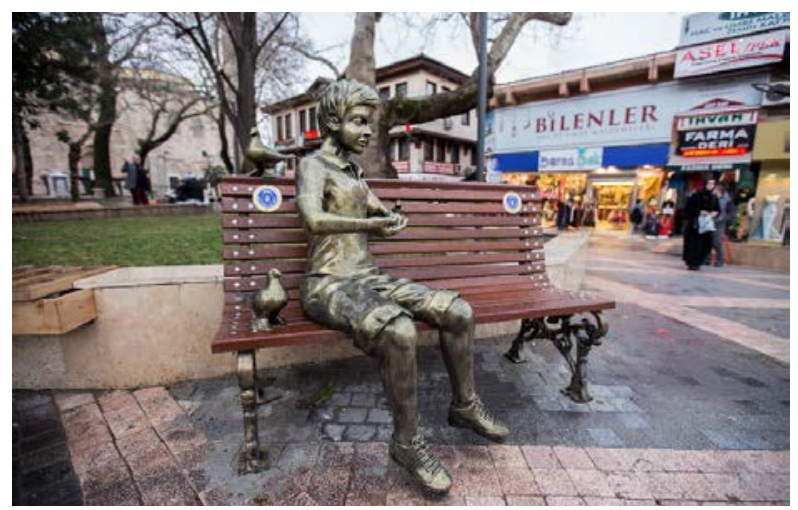

Figure 26. Statue of Child Feeding Birds (bttps:// wmw.bursa.bel.tr/ hunerli-eller-sebre-deger-katiyor-duzeltme/ haber/23156/) 


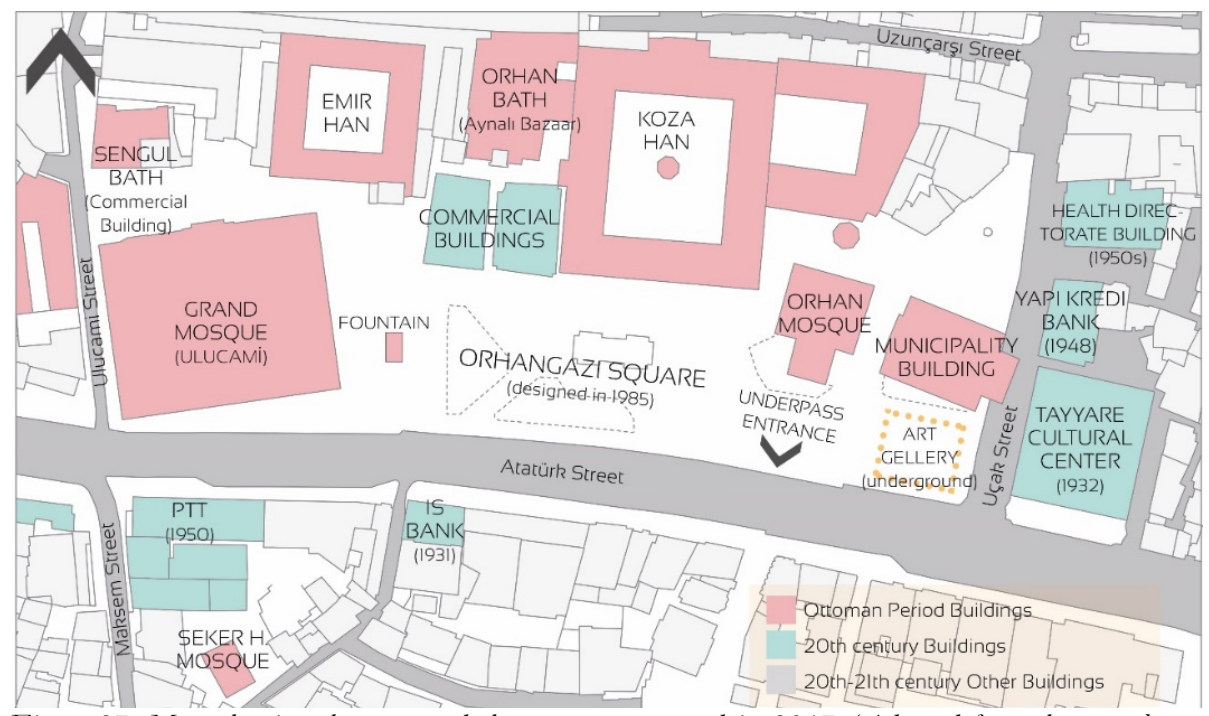

Figure 27. Map showing the area and the structures around in 2017 (Adapted from the actual map of Bursa, Bursa Metropolitan Municipality archive, 2018)

When the present situation of the square is examined, it is observed that it preserved its condition arranged in 1985; it is bordered by Ataturk Street on the south, the Orhan Mosque and the Municipality building on the east, Koza Han on the north and the Grand Mosque on the west (Figure 27). The access from the west of the square to Ataturk Street is made via stairs and ramps (Figure 28) and on the east, an underground passage with shops (Figure 29) provide the connection. The abundance of trees on the part of the square, which is close to the entry of the Grand Mosque, has caused excessive shadowy areas and the seating units in this area are frequently used. The Saylgan Passage and the commercial building located next to it still continue to be used with the same function. The Governor Munir Pasha fountain located on the east of the Grand Mosque with two facades facing the east and the west serves both the court of the Grand Mosque and the square. Again, in this section, there is a also small cafe which is difficult to notice among the trees. It is observed that lots of people stop to take photos around the pool and again tourist groups gather around the pool. The access to the first floor of Koza Han is enabled from the square level and from the north side of the pool. There are restrooms located under the square level which are accessed by stairs. There are seating units in the section of the square, which is close to the Orhan Mosque and it is observed that there are usually lots of people doing shopping and using the underground passage in this area. 


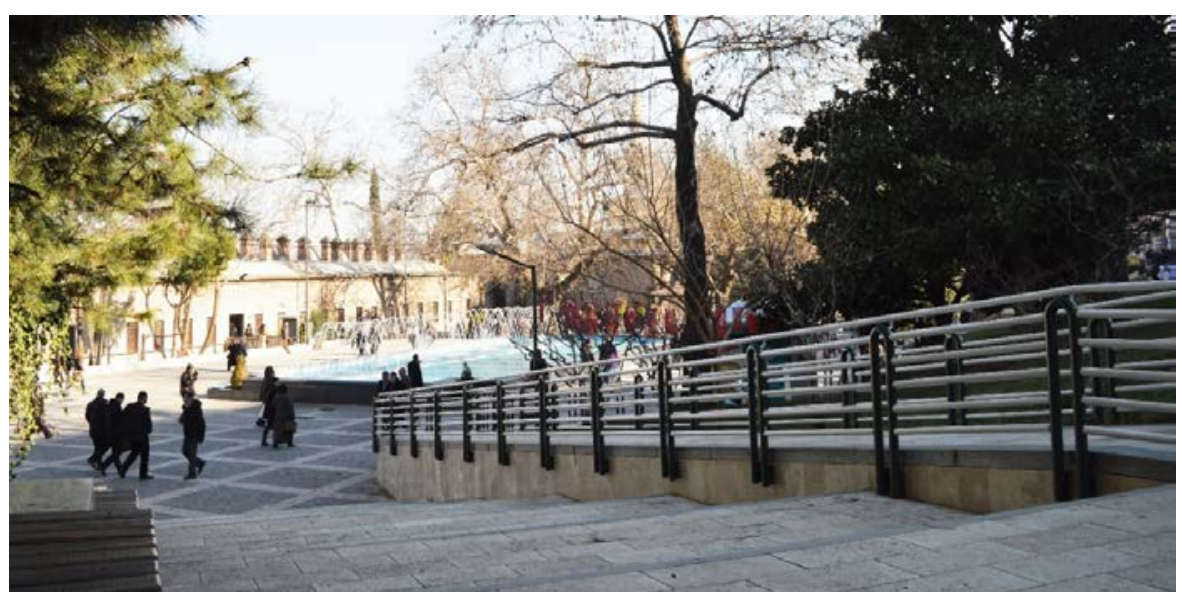

Figure 28. Ramps and stairs connecting Ataturk Street with the Orhan Gazi Square (Authors' archive, 2017)

Moreover, under the stairs connecting the underground passage with Tayyare Cultural Center (previously Tayyare Cinema) is Sefik Bursalı Art Gallery. Above the art gallery (Figure 30) is a small square hosting temporarily organized exhibitions. The stairs going from here down to the square have been renewed in the recent period and different landscape elements and seating elements have been evaluated together with the stairs. At the level of Ataturk Street, above the underground passage, there is a cafe facing the square.

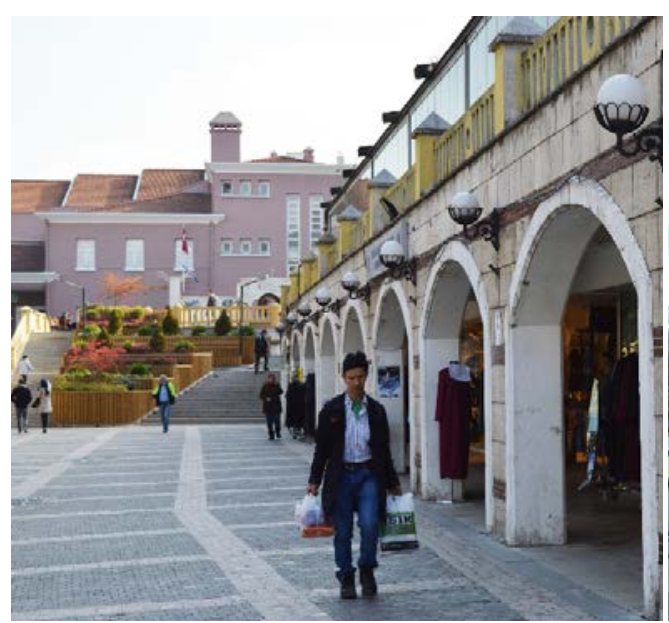

Figure 29. Underground Passage at the square level and Tayyare Cultural Center at the Ataturk Street level (Authors' archive 2017)

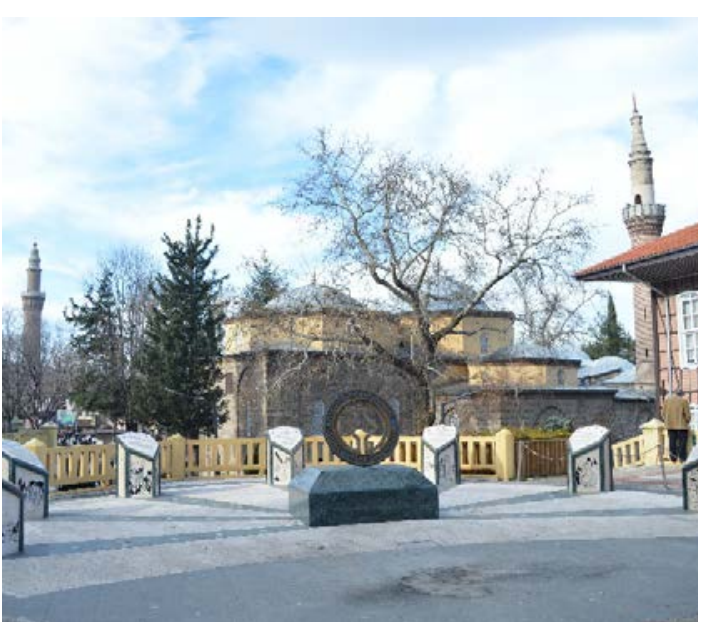

Figure 30. Small square above the underground passage at the Ataturk. Street level (Authors' archive 2017)

Besides being an area where many people stop, have a sit and wait all day, the square is a place providing a passage through the buildings around it for many people (Figures 31 and 32). At the same time, the square also hosts different activities on different dates 
all year. Ramadan festivities, offering ashura, concerts are some of the organized activities.

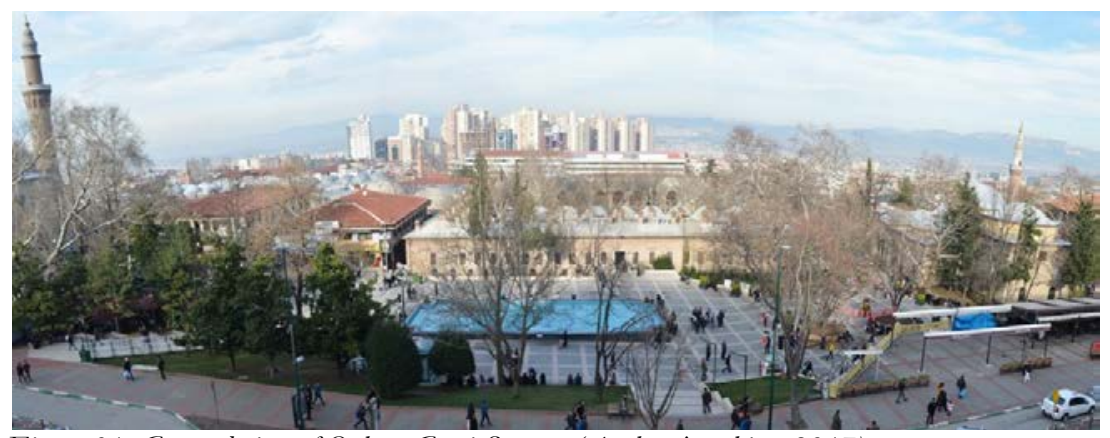

Figure 31. General view of Orban Gazi Square (Authors' archive, 2017)

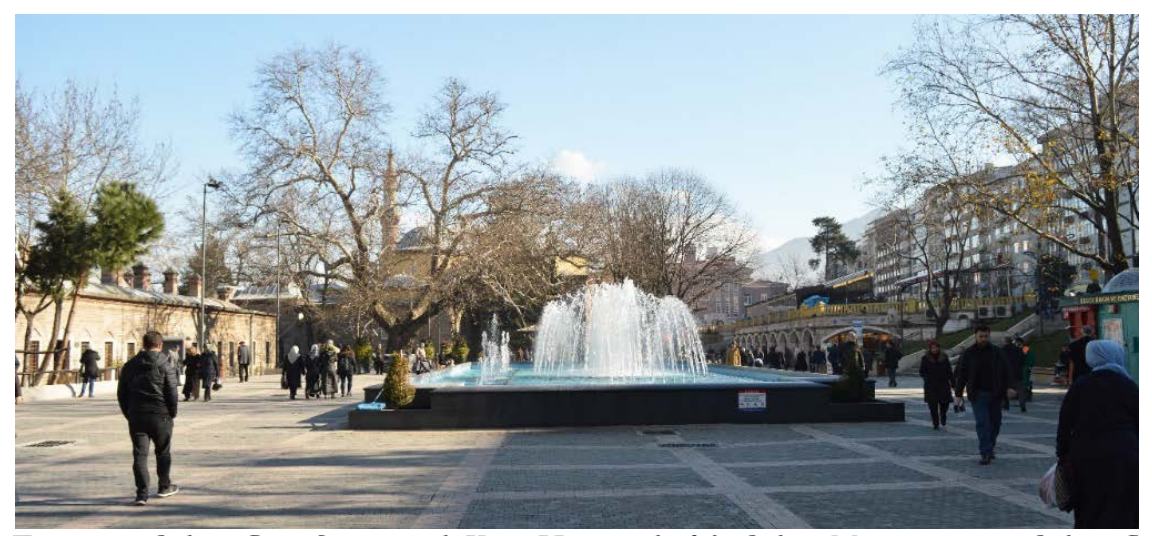

Figure 32. Orhan Gazi Square with Koza Han on the left, Orhan Mosque across, Orhan Gazi underground passage and Ataturk Street on the right and the pool in the middle (Authors' archive 2017)

\section{Conclusion}

Today, the Orhan Gazi Square is a public open space which is important for the city of Bursa and used by the city dwellers frequently. However, it is known that before the area reached its present condition and acquired the characteristic of a square, it had occupied a more different place in the urban pattern. This study aimed to reveal what physical changes the Orhan Gazi Square have undergone from past to present, what structures had surrounded it within the course of time and how it has been used.

It is observed that the area was used as a place having a commercial function prior to the Ottoman period and the construction activities in the area started with the establishment of the Ottoman Empire. In the Ottoman period, different structures were added to the surroundings of the area and these structures served especially to the commercial actvities of the city. In the 17 th and 18 th centuries, the economic recession experienced in the city helped to preserve the structures in the area and its surroundings physically. However, under the effect of modernization, the need for buildings with new 
functions led to the transformation of the area. At the same time, the presence of motor vehicles in the urban transportation led to the arrangement and widening of roads. It can be stated that the construction activities having started in the late 19th century continued in the first years of the Republic as well. In this respect, it is observed that buildings such as the Ottoman Bank, the Turkish Aeronautical Association Branch, the Romans Tea Garden, the Istanbul Cinema, the Tayyare Cinema took part in the area. Again, in this period, pre-industrial city image of Bursa was changed and the area was made to function as the nodal point of the transportation systems. That's why, garages, bus stops, petrol stations appeared in the area. The square was turned into an area serving vehicle transport rather than pedestrian transport and this continued until the end of the 20th century.

The square, as one of the most significant requirements of today's city, has taken place on the agenda of the city of Bursa as well. In this respect, the area underwent a great functional and physical change and acquired the identity of a square in 1985. It can be stated that the recent interventions that took place during the last decades made the area a breathing point inside the city with its aspects of meeting the requirement for an open space in the city center and being close to the historical trade center. Moreover, it is known that the square is called as the 'Orhan Gazi Park' in the press, on the internet environment and by many of its users. On the other hand, although the idea of rearranging the Orhan Gazi Square has remained on the agenda in recent years, it is considered that there is no need to make any radical interventions in the square. The city dwellers' changing needs can be met with small-scale arrangements and changes to be made on site.

\section{References}

Altan Oteli, “Şimdiki Sayılgan-Uluca Pasaj1 70’li Yıllar.” 12.21.2017. Bursa'da Nerede, https://www.bursadanerede.com/haberler/eski-bursa-fotograflari-fotograf-galerisi/simdikisayilgan-uluca-pasaji-70li-yillar

Ataberk, Tevfik. "Bursa Orhan Cami Yanı." 12.23.2017. Pinterest, https://tr.pinterest.com/pin/448389706636196006/

Basın Bülteni, "Hünerli Eller Şehre Değer Katıyor." 12.29.2017. Bursa Büyü̈şsehir Belediye Başkanlĭg, https://www.bursa.bel.tr/hunerli-eller-sehre-deger-katiyor--duzeltme-/haber/23156/

Baykal, Kazım. Bursa ve Anıtları. İstanbul: Türkiye Anıt Çevre Turizm Değerlerini Koruma Vakfi, 1982.

Bengisun, Onur. “Antik Edebi Kaynaklarda Bithynia ( İ.Ö. 333 - İ.S. 284 ).” Master's Thesis, Ege University, 2010.

Birgül, M. Fatih. Hasan Taib Efendi-Hatıra Ya da Bursa’nın Aynası. Ankara: Yeșil Şehir Kitaplığı, 2009.

Bursa Haber, “Orhangazi Parkı'nda Çalışmalar Ne Zaman Tamamlanacak?.” 03.02.2018. Bursa'da Birgün. Com. http://bursadabirgun.com/orhangazi-parkinda-calismalar-ne-zaman-tamamlanacak5922.html.

Bursa Metropolitan Municipality map archive. Actual map of Bursa, 2018.

Cezar, Mustafa. Typical Commercial Buildings of the Ottoman Classical Period and the Ottoman Construction System. Trans: A. E. Uysal. İstanbul: Türkiye İş Bankası Kültür Yayınları, 1983.

Çetin, Osman. "15. Yüzyılda Balıkpazarı Mahallesi ve Çarşısı," Çarşının Öyküsü, Eds., Neslihan Dostoğlu, Necmi Gürsakal, H. Basri Öcalan, Aziz Elbas. İstanbul: Bursa Araştırmaları Merkezi, 2010.

Çobanoğlu, Esra."Bursa Tarihi Çarşı ve Hanlar Bölgesi’nde Çeşmeler," Çarşımm Öyküsü, Eds., Neslihan Dostoğlu, Necmi Gürsakal, H. Basri Öcalan, Aziz Elbas. İstanbul: Bursa Araştırmaları Merkezi, 2010. 
Demirağ, Bülent. "İhsan Celal Antel'in Objektifinden Masal Bursa: Evvel Zaman İçinde Bursa," Bursa'da Yasam Dergisi, 2012.

Doruk, Mazhar Yüce. 'Setbaşı Postane Piyasası Huzur Turu: Eski Bursa'ya Son Yolculuk," Bursa'da Yaşam Dergisi, 2012.

Dostoğlu, Neslihan T. "Bursa'da Orhangazi Meydanı ve Arolatlar'ın Katkısı," Mimar Anlam Beğeni, Ed., Gülnur Güvenç. İstanbul: Yem Yayınları, 1999.

Dostoğlu, N., Gürsakal, N., Öcalan, H. B. \& Elbas A. (2010). "Bursa City Maps.” Carşınnn Öyküsü. İstanbul: Bursa Araştırmaları Merkezi,2010.

Dörtok Abac1, Zeynep. "Bursa'nın Kent Dokusu Üzerine Tarihsel Bir İnceleme (17.Yüzyll).” Master's Thesis, Uludag University, 2001.

Durak, Selen. Vural Arslan, Tülin. “Geleneksel Osmanlı Kenti'nden Modern Cumhuriyet Kenti'ne: Bursa'da İdari Yapılar," Bursa Kültür Varlklar Envanteri: Antsal Eserler, Eds., H. Dostoğlu, N. Dostoğlu, Bursa: Bursa Büyükşehir Belediyesi Yayınları, 2011.

Hızlı, Mefail. "Orhan Gazi Döneminde Eğitim ve Eğitim Kurumları.” Uluslararası Orhan Gą̧ ve Dönemi Sempozyumu, Ed., İ. Selimoğlu. İstanbul: Osmangazi Bel. Yayınları, 2011.

Kaplanoğlu, Raif. "Belge ve Fotoğraflarla Bursa'nın İlk Caddesi: Atatürk Caddesi: Eski Bursa'ya Son Yolculuk," Bursa'da Yaşam Dergisi, 2012.

Kemankaş, İsmail. "Sanal Alemde Eski Bursa'yı Yaşatanlar: Evvel Zaman İçinde Bursa," Bursa'da Yaşam Dergisi, 2012.

Kılıç, Mustafa. "Nerede O Eski Bursa." 07.23.2018. Haber 16. https://www.haber16.com/fotogaleri/nerede-o-eski-bursa-1/44/resim/4

Kırayoğlu, Kerem. "Bir Osmanlı Şehri Bursa'da Şehir Merkezi/Hanlar Bölgesi Sorunsalı," Master's Thesis, Istanbul Technical University, 2004.

Kırayoğlu, Mithat. "Bursa’nın Görsel Mirası: Evvel Zaman İçinde Bursa,” Bursa'da Yaşam Dergisi, 2012.

Köprülü Bağbanc1, Özlem. "Bursa Hanlar Bölgesi Değişim Ve Dönüşüm Sürecinin İncelenmesi Ve Bölgenin Korunması Üzerine Bir Araştırma,” Doctoral Dissertation, Yildiz Technical University, 2007.

Neşri, Mehmed. "Kitab-1 Cihannüma I. Cilt Neşri Tarihi," Eds., Mehmet Altay Köymen, Faik Reşit Unat. Ankara: Türk Tarih Kurumu Basımevi, 1987.

Oğuzoğlu, Yusuf. "Bursa Çarşısı'ndaki Restorasyon Çalışmalarına Arşiv Belgelerinin Katkısı," Carşımm Öyküsü, Eds., Neslihan Dostoğlu, Necmi Gürsakal, H. Basri Öcalan, Aziz Elbas. İstanbul: Bursa Araştırmaları Merkezi, 2010.

Öcalan, Hasan Basri. Yavaş, Doğan. Sevim, Sezai. Bursa Vakfiyeleri 1. Bursa: Bursa Büyükşehir Belediyesi, 2013.

Pay, Salih. "Ulucami Çevresindeki Han, Çarşı, Mezar ve Medreseler," Bursa Ulucami, Eds., Bilal Kemikli Ankara: Bursa Araştırmaları Merkezi, 2012.

Polat, Sibel. "Kamusal Dış Mekanlarda Mimari Kimliği Değerlendirmek İçin Bir Yöntem Önerisi: BursaCumhuriyet Alanı Örneği,” Doctoral Dissertation, Uludag University, 2013.

Saint-Laurent, Beatrice. "Bir Tiyatro Amatörü: Ahmed Vefik Paşa Ve 19. Yüzyllın Son Çeyreğinde Bursa’nın Yeniden Biçimlenmesi," Modernlessme Sürecinde Osmanl Kentleri, Eds., Paul Dumont, F. Georgeon. İstanbul: Tarih Vakf1 Yurt Yayınları, 1996.

Şahin, Belkıs Ece. "Meydanların Kentsel Yaşama Katkısı Üzerine Bir İnceleme: Bursa Örneği," Master’s Thesis, Uludag University, 2006.

Şehitoğlu, Elif. “Osmanlı Dönemi Ticaret Merkezinde Çarşı Hamamları,” Çarşının Öyküsü, Eds., Neslihan Dostoğlu, Necmi Gürsakal, H. Basri Öcalan, Aziz Elbas. İstanbul: Bursa Araştırmaları Merkezi, 2010.

Topçular, Taner. “Ottoman Bank Building.” 12.23.2017. Pinterest, https://tr.pinterest.com/pin/ 515240013599572818/

Türk, Ebru K. “Orhangazi Parkı'na Yeni Havuz Yapılıyor, 03.12.2006.” WowTurkey. http://wowturkey.com/forum/viewtopic.php?t=33872.

Ussoy, Nedim. "Ulucami Otobüs Duraklar1." 12.23.2017. WowTurkey, http://wowturkey.com/forum/viewtopic.php?t=9701\&start=780

Vural Arslan, Tülin. "Bursa Kapalı Çarşı ve Hanlar Bölgesi'nin İyileştirilmesinde İlk Bütüncül Yaklaşım: Piccinato Projesi,” Çarşının Öyküsü, Eds., Neslihan Dostoğlu, Necmi Gürsakal, H. Basri Öcalan, Aziz Elbas. İstanbul: Bursa Araştırmaları Merkezi, 2010.

Yalman, Bedri. Bursa’nın Kültür ve Tabiat Varlıkları 3. Bursa: Bursa Çekirge Lions, 2011. 
Yavaş, Doğan. “Orhan Gazi Dönemi Bursa Eserleri,” Uluslararası Orhan Gazi ve Dönemi Semposyumu, Ed., İ. Selimoğlu. İstanbul: Osmangazi Belediyesi Yayınları, 2011.

Yavaş, Doğan. “Bursa Ulucami,” Türkizye Diyanet Vakfi, İslam Arasttrmalar Merkę̧i. Cilt 42 (2012): 88-89. url: http://www.islamansiklopedisi.info/dia/ayrmetin.php?idno $=420088$

Yazman, Derya. “1. Ödül Orhangazi Meydanı ve Çevresi Kentsel Tasarım Proje Yarışması.” 12.22.2017. Arkitera. http://www.arkitera.com/proje/619/1-odul-bursa-buyuksehir-belediyesi-orhangazimeydani-ve-cevresi-kentsel-tasarim-proje-yarismasi.

Yazman, Derya “2. Ödül Orhangazi Meydanı ve Çevresi Kentsel Tasarım Proje Yarışması," 12.22.2017. Arkitera. http://www.arkitera.com/proje/614/2-odul-bursa-buyuksehir-belediyesi-orhangazimeydani-ve-cevresi-kentsel-tasarim-proje-yarismasi.

Yazman, Derya. "3. Ödül Orhangazi Meydanı ve Çevresi Kentsel Tasarım Proje Yarışması.” 12.22.2017. Arkitera, http://www.arkitera.com/proje/622/3-odul-bursa-buyuksehir-belediyesi-orhangazimeydani-ve-cevresi-kentsel-tasarim-proje-yarismasi.

Yenal, Engin. Bir Masaldı Bursa. İstanbul: Yap1 Kredi Yayınları, 1996.

Yenal, Engin. “Osmanlı Başkenti Bursa,” Ed., İsmail Cengiz. Ankara: Bursa Araştırmaları Merkezi, 2011.

Yenen, Zekiye. "Vakıf Kurumu - İmaret Sistemi Bağlamında Osmanlı Dönemi Türk Kentlerinin Kuruluş Ve Gelişim İlkeleri,” Unpublished Doctoral Thesis, Istanbul Technical University, 1987. 